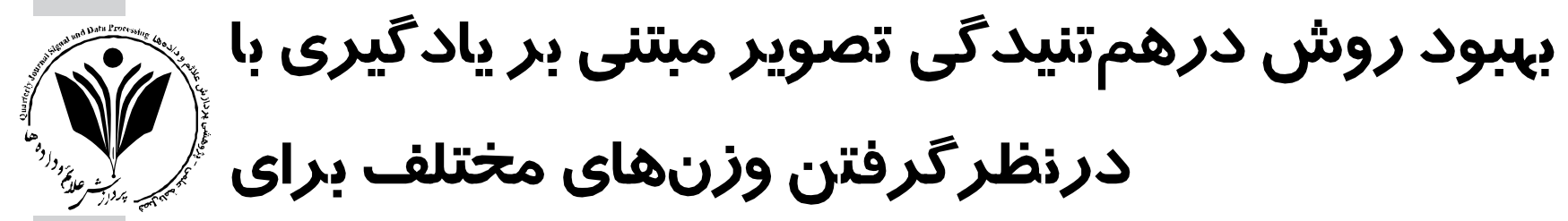

زمينه و يسئ زمينه

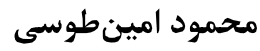

دانشكدة رياضى و علوم كامييوتر، دانشكاه حكيم سبزوارى، سبزوار، ايران

جكيده

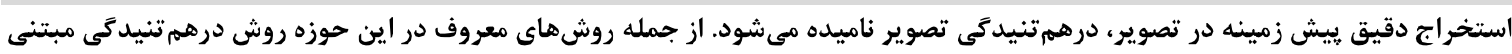

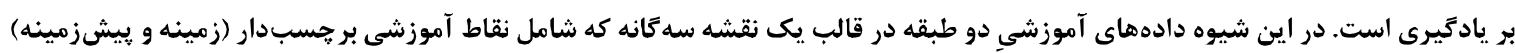

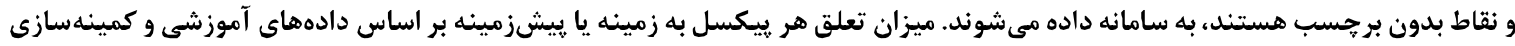

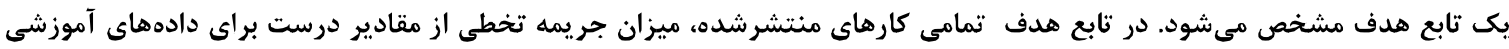

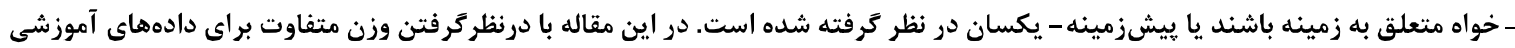

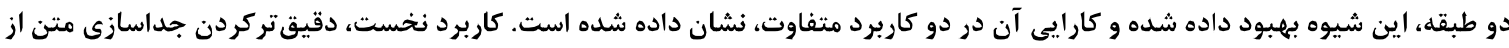

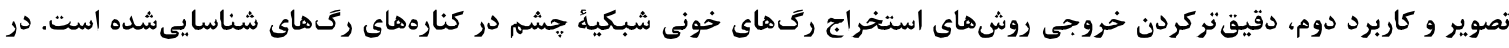

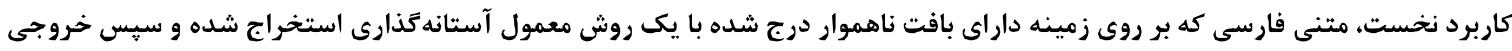

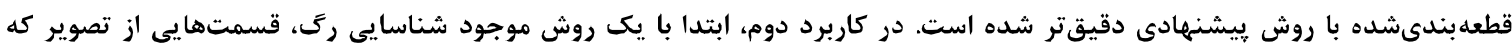

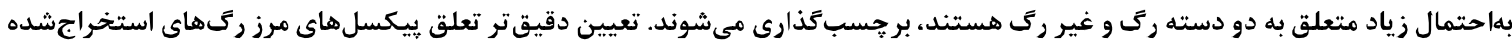

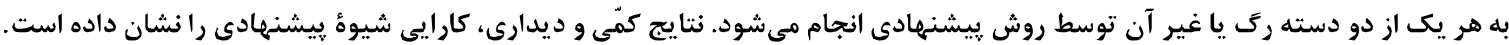

وارَّان كليدى: قطعبندى تصوير، درهمتنيدَى تصوير، استخراج رك، يادَّيرى ماشين، استخراج متن از تصوير

\title{
Enhancement of Learning Based Image Matting Method with Different Background/Foreground Weights
}

\author{
Mahmood Amintoosi \\ Faculty of Mathematics and Computer Science, Hakim Sabzevari University, Sabzevar, Iran
}

Abstract

The problem of accurate foreground estimation in images is called Image Matting. In image matting methods, a map is used as learning data, which is produced by those pixels that are definitely foreground, definitely background ,and unknown. This three-level pixel map is often referred to as a trimap, which is produced manually in alpha matte datasets. The true class of unknown pixels will be estimated by minimizing of an objective function. Several methods for image matting has been proposed. The learning-based method is one the pioneering works which is the basis of many other approaches in the field of image matting. In this method it is assumed that each pixel's alpha value is a linear combination of its associated neighboring pixels. A Laplacian matrix in the objective function shows the similarity of the pixels. The coeffieients of the linear combination are estimated with a local learning process by minimizing a quadratic cost function. The method of Lagrange multiplier and ridge regression technique are used for estimation of alpha values. In this objective

* Corresponding author * نويسندة عهدهدار مكاتبات 
function the violation of the predefined training pixels' alpha values from their true values is controlled by a penalty term. Considering this coefficient as infinity, forces the matte (alpha) value to be 1 for the labeled foreground pixels and 0 for background. The weight of this penalty term still was taken equal for all training samples. In this paper the performance of the matting method is increased by considering different weights for different learning pixels. The good performance of the proposed method is demonstrated in two applications. The first application is improving the quality of a text extraction method and the second application is enhancement of an eye retinal segmentation system. In the first application, a Persian text which is fused onto a textured background is extracted by a thresholding method. After that the segmented output is enhanced by the proposed matting method. In the second application, segmentation is done with an existing vessel extraction method. The edges' pixels of detected vessels that may be classified inaccurately are classified by the proposed image matting method. Subjective and objective comparisons show the better performance of the proposed method.

Keywords: Image Matting, Image Segmentation, Machine Learning, Text Extraction, Retinal Vessel Segmentation

ييشزمينه و ميزان تيركى بيشزمينه (alpha matte) در آن

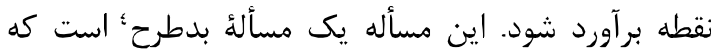

يزوهش هاى متعدى را در ساليان اخير به خود معطوف نموده

فرض كنيد مجموعه بيكسل هاى I با ك......

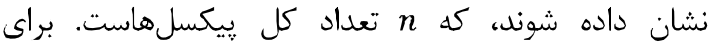

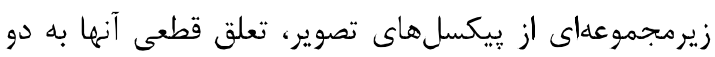
زيرمجموعه زمينه و ييشزمينه مشخص است كه به بهعنوان

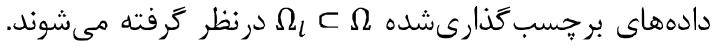
مقدار م براى اين دو دسته صفر و يك است كه با نواحى سياه

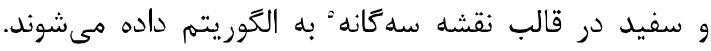
برآورد آلفا بهعنوان محاسبه مقدار م براى مجموعهاى از

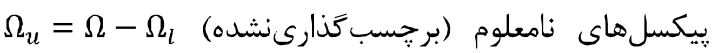
digital alpha matting تعريف مى يا

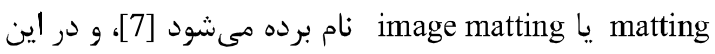
نوشتار از آن با نام "ادرهمتنيدكى تصوير ه ياد خواهد شد.

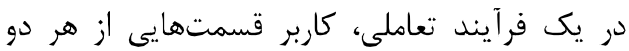

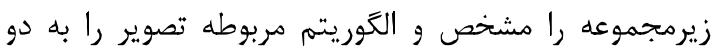

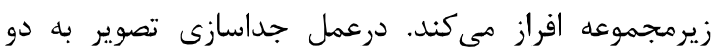
قسمت زمينه و شيئ، كاربر از طريق ايجاد يك نقشه سه كَانه، سامانه را آموزش مى دهدد. نقشه بلنحوى ايجاد مي شئود كه آن نواحى از تصوير كه مطمئناً متعلق به زمينه هستند با رنت

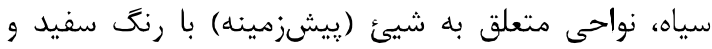
نواحى داراى عدم قطعيت با رنت خاكسترى مشخص شوند. نقاط متناظر با نواحى سياه و سفيد اين نقشه، در تصوير اصلى دهى بلعنوان دادههاى آموزشى درنظر كرفته مىشوند و هدف اين روش تخمين برجسب ساير نقاط (ييكسل هاى متناظر با نقاط خاكسترى) با استفاده از اين دادههاى آموزشى است.

${ }^{4}$ Ill-posed
${ }^{5}$ Trimap

${ }^{4}$ Ill-poscd
${ }^{5}$ Trimap

\section{-}

شناسايى اشياى موجود در تصوير يكى از معروفترين مسائل

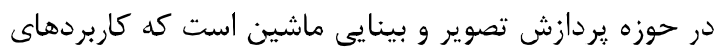

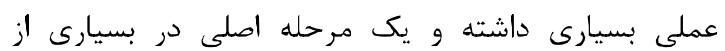
سامانههاى مبتنى بر يردازش تصوير محسوب ميى شود. از جمله

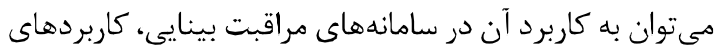
يزشكى و شناسايى بصرى حروف اشاره كرد.

شناسايى اشيا درواقع يك مسأله قطعهبندى است كرو كه

روشهاى متعددى براى آن تاكنون عرضه شده است؛ يكى از

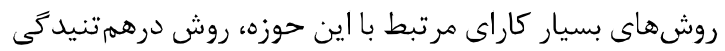

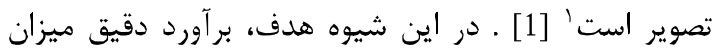

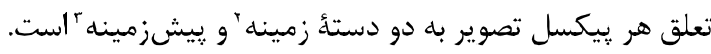

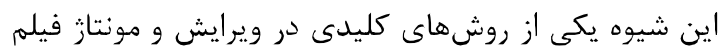

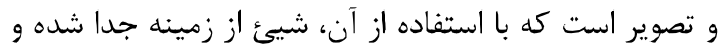

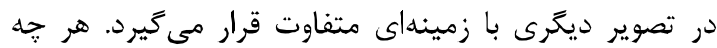
برآورد ناحيه ييشزمينه دقيقتر باشد، عمل تركيب شيئ با ديا

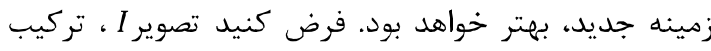
خطى از زمينه B و ويشزمينه F

$I=\alpha F+(1-\alpha) B$

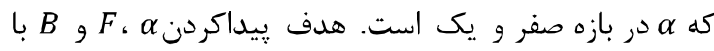

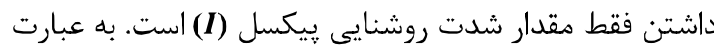

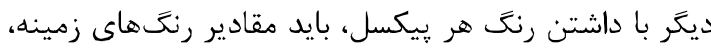

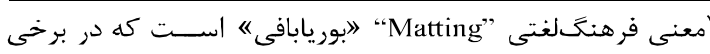

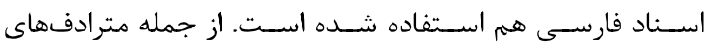
Matting

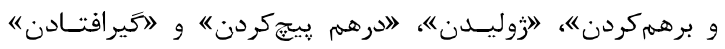

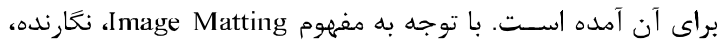

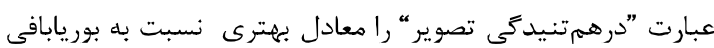

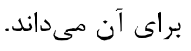

${ }^{2}$ Background

${ }^{3}$ Foreground 
جهار نتايج آزمايشهاى انجامشده را بر روى دو كاربرد متفاوت

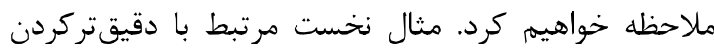

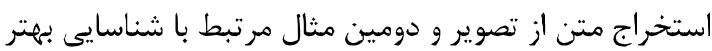

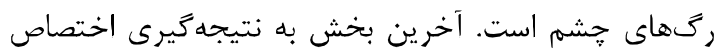
كاده شده است.

\section{r- روش درهمتنيدگى تصوير مبتنى بر يادَيرى}

همان كونه كه اشاره شد، منظور از درهمتنيدگى تصوير، تخمين دقيق بيشزمينه در تصوير و ويدئو است. در اين بخش

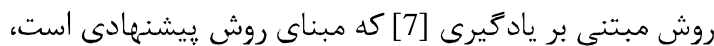
بيان خواهد شد.

در روش مبتنى بر يادخيرى براى هر ويكسل

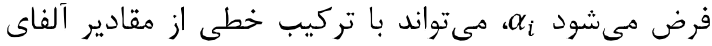

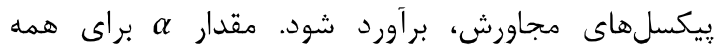

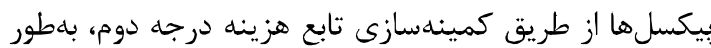
همزمان برآورد مىشود. فرض كنيد

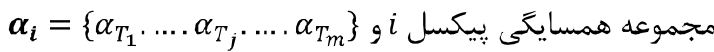

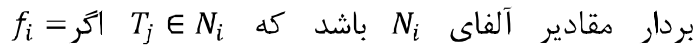
خطي خطى در نظر كرفته شود، آنكاه تركيب خطى ضرايب رائ را براى ني

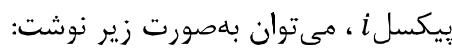

$\alpha_{i}=f_{i}^{T} \boldsymbol{\alpha}_{i}$

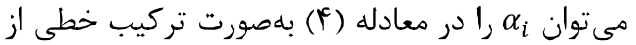

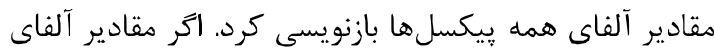

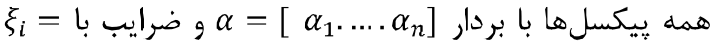

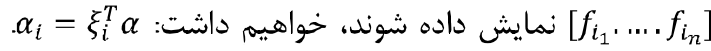

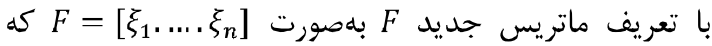
ب $\alpha=F^{T} \alpha$ بازنويسى كرد. اكر F معلوم باشد، آلفا از طريق كمينهسازى تابع درجه

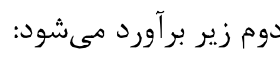

$\underset{\boldsymbol{\alpha}}{\operatorname{argmin}}\left\|\boldsymbol{\alpha}-F^{T} \boldsymbol{\alpha}\right\|^{2}+c\left\|\boldsymbol{\alpha}_{l}-\boldsymbol{\alpha}_{l}^{*}\right\|^{2}$

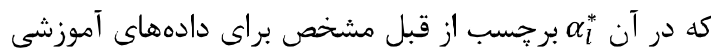

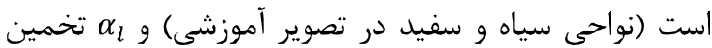
همين نقاط در م كمينه است.

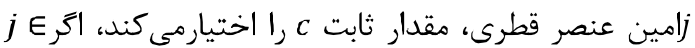
$\alpha^{*} \alpha^{*} \Omega_{l}$ بهطول n در نظر كرفته شود، كه ز أمين عنصر آن مقدار معلوم
در [8] از روش فرم بسته' براى حل مسأله استفاده شده است. در اين شيوه فرض مىشود F و

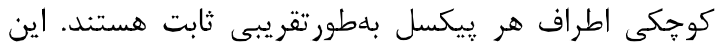

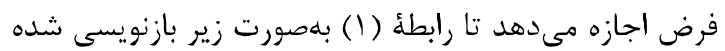

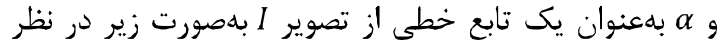

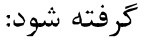

$\alpha_{i}=a I_{i}+b \quad \forall i \in w$

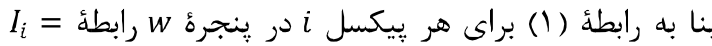
年 $\alpha_{i} F_{i}+\left(1-\alpha_{i}\right) B_{i}$

$$
\begin{aligned}
& \alpha_{i}\left(F_{i}-B_{i}\right)=I_{i}-B_{i} \\
& \quad \Rightarrow \alpha_{i}=\frac{1}{F_{i}-B_{i}} I_{i}+\frac{-B_{i}}{F_{i}-B_{i}}
\end{aligned}
$$

لذا مسأله از طريق كمينهسازى تابع زير انجام مىشود:

$J(\alpha . a . b)=\sum_{k \in I}\left(\sum_{i \in w_{k}}\left(\alpha_{i}-a_{k} I_{i}-b_{k}\right)^{2}+\varepsilon a_{k}^{2}\right)$

كل

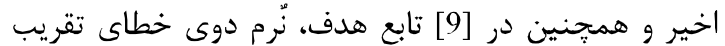
است. در مرجع [5] با هدف حفظ بهتر لبههاى تصوير از نرم

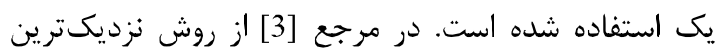

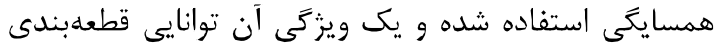

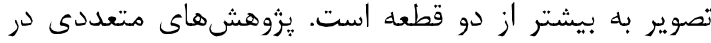
حوزه درهمتنيدكى تصوير انجام شده است؛ تا آنجا كه نغارنده مطلع است، در كارهاى انجامشده، نمونههاى آموزشى متعلق آنق

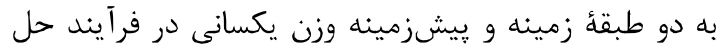

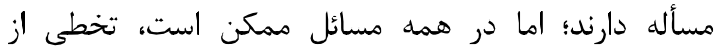
نمونههاى زمينه و يِيشزمينه اهميت يكسانى نداشته باشند.

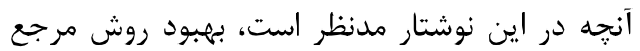
[7] است. در اين روش نيز وزن يكسانى براى نمونههاى

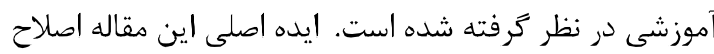

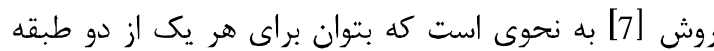

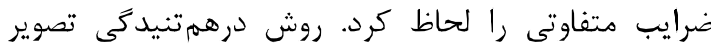

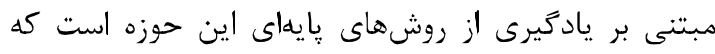

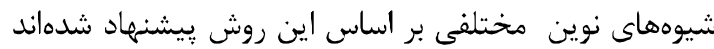

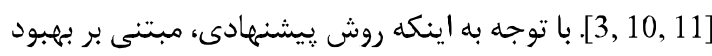

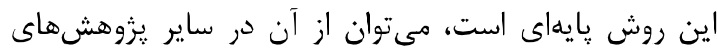
بركرفته از اين روش نيز استفاده كرد.

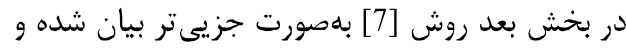

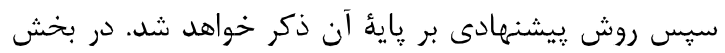

\footnotetext{
${ }^{1}$ Closed Form
} 
اتر اسكالرهاى

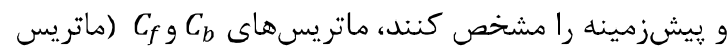

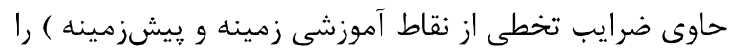

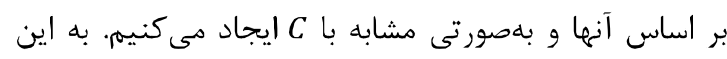
ترتيب رابطه (ع) بهصورت زير در خواهد آنهاب آمد:

$\arg \min _{\alpha \in \mathbb{R}^{n}}\left[\alpha^{T}\left(I_{n}-F\right)\left(I_{n}-F\right)^{T} \alpha+\right.$

$\left.\left(\alpha-\alpha^{*}\right)^{T} C_{b}\left(\alpha-\alpha^{*}\right)+\left(\alpha-\alpha^{*}\right)^{T} C_{f}\left(\alpha-\alpha^{*}\right)\right]$

با تركيب مناسب ماتريسهاى

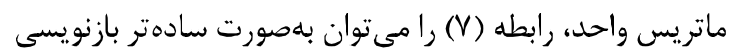

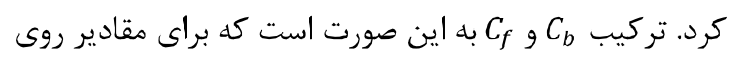

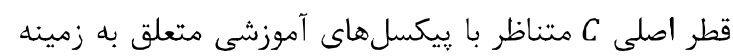

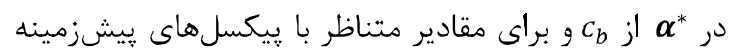

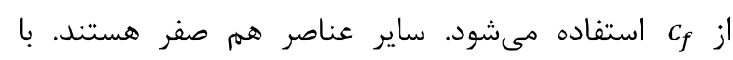
محاسبه C بر اساس ماتريسهاى C

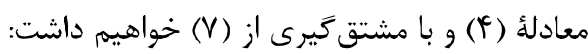

$\boldsymbol{\alpha}=\left(\left(I_{n}-F\right)\left(I_{n}-F\right)^{T}+C\right)^{-1} C \boldsymbol{\alpha}^{*}$

اكر ضرايب تركيب خطى در معادله (4) معلوم باشند،

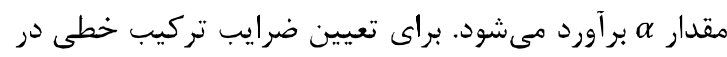

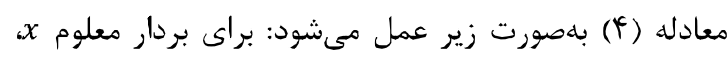

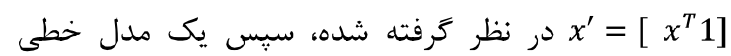
آلفارنخ بلهورت زير انتخاب مى شودئ

$\alpha=x^{T} \beta+\beta_{0}=x^{\prime T}\left[\begin{array}{l}\beta \\ \beta_{0}\end{array}\right]$

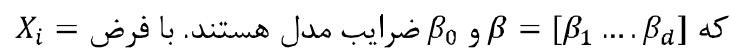

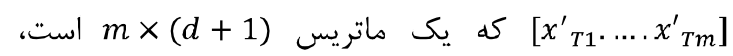

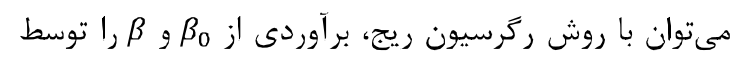

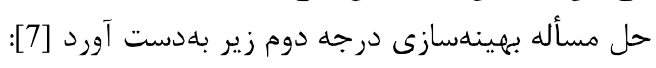
$\underset{\beta, \beta_{0}}{\operatorname{argmin}}\left\|\boldsymbol{\alpha}_{\boldsymbol{i}}-X_{i}\left[\begin{array}{l}\beta \\ \beta_{0}\end{array}\right]\right\|^{2}+\lambda_{r}\left[\begin{array}{l}\beta \\ \beta_{0}\end{array}\right]^{T}\left[\begin{array}{l}\beta \\ \beta_{0}\end{array}\right]$ جواب بهينهُ معادله بالا بهصورت زير حاصل مىشود:

$\left[\begin{array}{l}\hat{\beta} \\ \hat{\beta}_{0}\end{array}\right]=\left(X_{i}^{T} X_{i}+\lambda_{r} I\right)^{-1} X_{i}^{T} \boldsymbol{\alpha}$

با جاى كذارى معادله (• (1) در معادله (9)، $f^{\prime}$ بهصورت

حاصل مىشود كه مستقل $f_{i}=\left(X_{i} X_{i}^{T}+\lambda_{r} I_{(m)}\right)^{-1} X_{i} x^{\prime}{ }_{i}$ إز

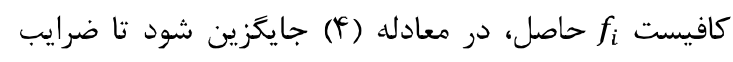

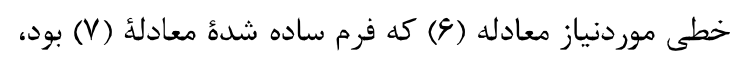

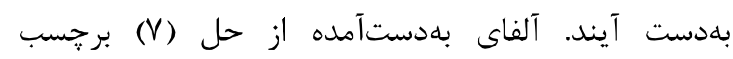
قطعهبندى ييكسل هاى تصوير است.
ذم $\alpha_{j}$

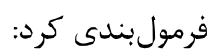

$$
\begin{aligned}
\underset{\alpha \in \mathbb{R}^{n}}{\operatorname{argmin}} & \boldsymbol{\alpha}^{T}\left(I_{n}-\boldsymbol{F}\right)\left(I_{n}-\boldsymbol{F}\right)^{T} \boldsymbol{\alpha} \\
& +\left(\alpha-\alpha^{*}\right)^{T} C\left(\alpha-\alpha^{*}\right)
\end{aligned}
$$

كه I ماتريس همانى است. با مشتق گيرى نسبت به $\alpha$ و برابر

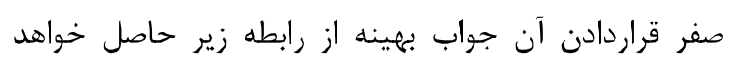
$\alpha=\left(\left(I_{n}-F\right)\left(I_{n}-F\right)^{T}+C\right)^{-1} C \alpha^{*}$

شد:

\section{r- روش بيشنهادى}

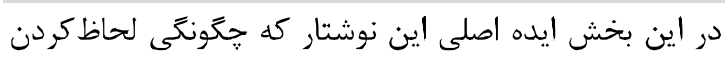

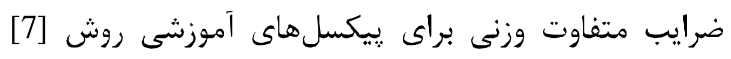

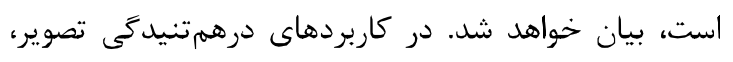

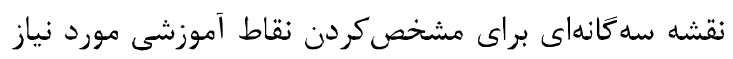

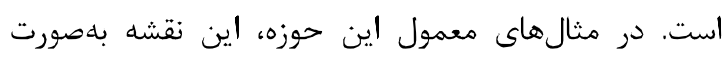

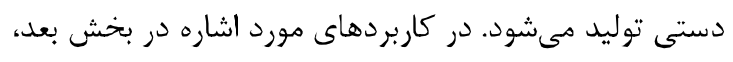

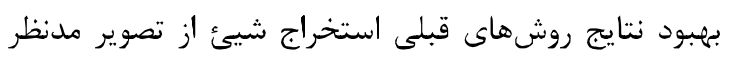

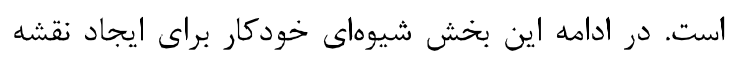

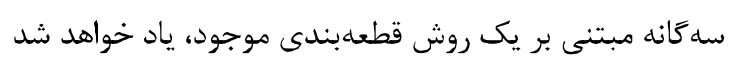
كه در بخش كاربردها مورد استفاده قرار مي مئيردي

\section{|-r- بهبود روش درهمتنيدكى تصوير مبتنى بر يادكيرى براى دقيقتركردن نتيجد

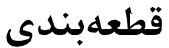

در بخش قبل اشاره شد كه ضريب تخطى مقادير برآورد شدهُ

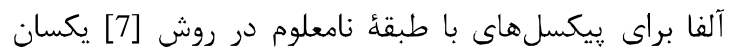

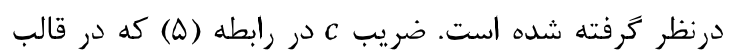

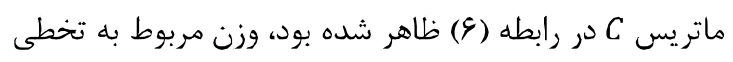

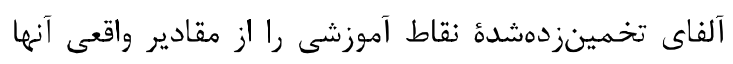

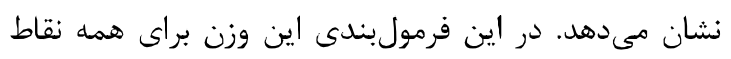

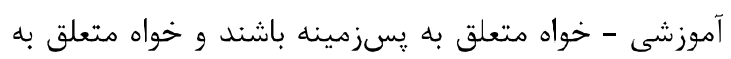
بيشزمينه - يكسان است.

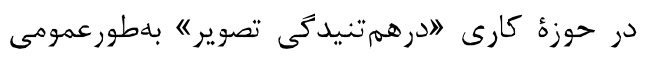

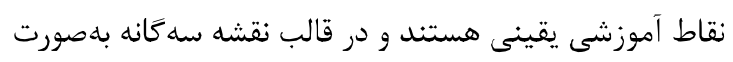
دقيق مشخص مىشود كه هر نقطه آموزشى متعلق بـ به كدام

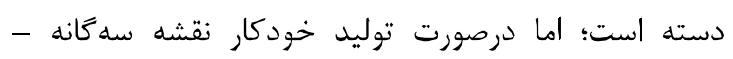

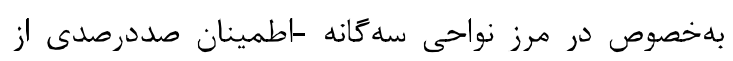

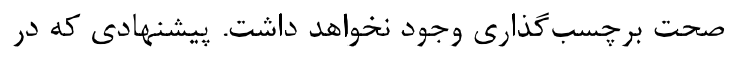

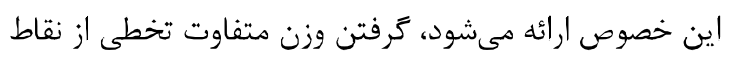

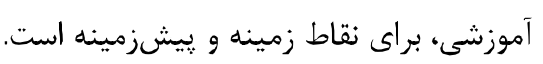


اين شيوه آن است كه با تغيير اندازه و شكل عنصر ساختارى" مى توان اندازه نواحى سفيد، خاكسترى و سياه در نقشه سهكانه را بهآسانى تغيير داد.

\section{F - Fاربر دها}

بهبود يِيشنهادى در اين مقاله بر روى روش [7]، مناسب

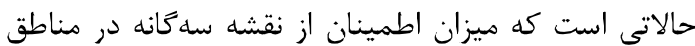

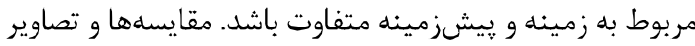

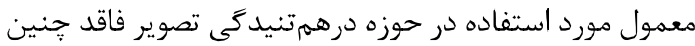
فرضى هستند؛ به همين دليل براى نمايش برترى شيوه

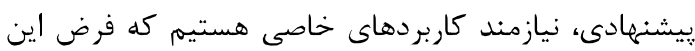

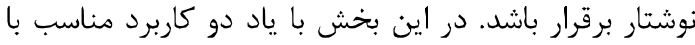

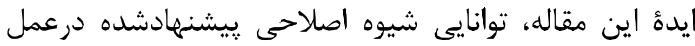

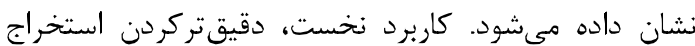

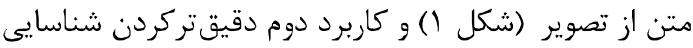
ركهاى خونى شبكيه جشم است.

\section{|- أ- دقيقتركردن نتايج استخراج متن از

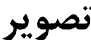

در نخستين كاربرد، مسألل دقيقتركردن استخراج متن از

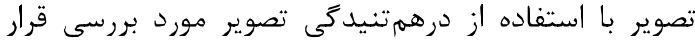

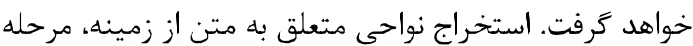

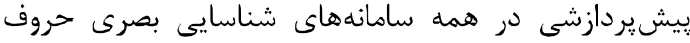

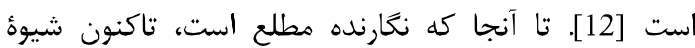
درهمتنيدگى تصوير براى دقيقتر كردن خروجى يك سامانه

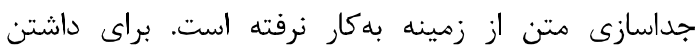

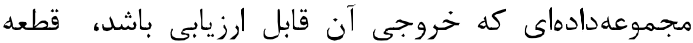

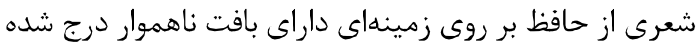

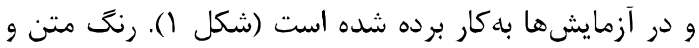

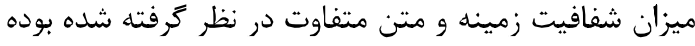

بذعنوان يك روش قطعهبندى تصاوير داراى متن، در

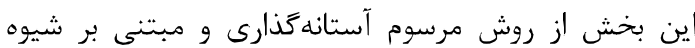

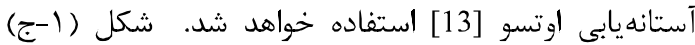
خروجى قطعهبندى تصوير ا(الف) با روش آستانه كذارى اوتسو آنسو

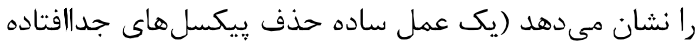

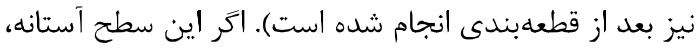

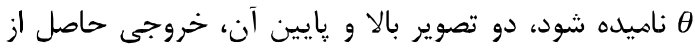
قطعهبندى با سطوح آستانه //.--

\footnotetext{
istructure Element

با متمايزكردن

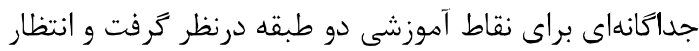
نتايجى متفاوت داشت. نتايج آزمايشهاى انجامشده اين اين حدس را تأييد كرده است.

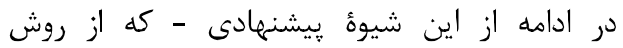

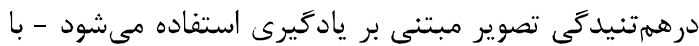

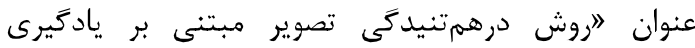
وزندهىشده" و يا بهاختصار 'WLbM ياد خواهد شد. r-r-r- توليد خود كار نقشه سه

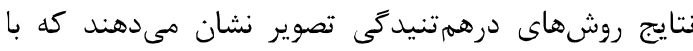

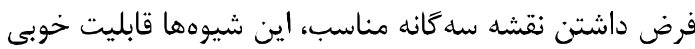
در جداسازى مرز دقيق شيئ و زمينه در تصاوير طبيعى دارند.

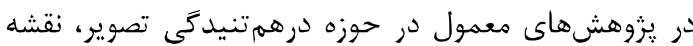

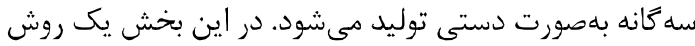

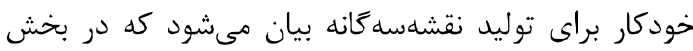
كاربرد شيوه يِيشنهادي بخش قبل مورد استفاده قرار خواهد

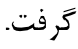

كاربردهاى مدنظر اين نوشتار، دقيقتركردن خروجى في قطعهبندى روشهاى يیشين است. با فرض داشتن روشى بيشين در قطعهبندى، براى توليد نقشه سه

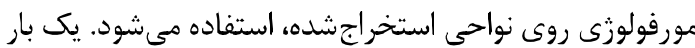

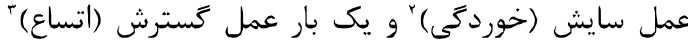
روى نواحى حاصل از قطعهبندى استخر اجشده، اعمال شده و

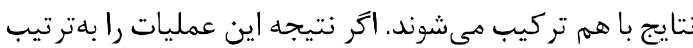
تصاوير E و D بناميم، در تصوير E ناحيه قطعهبندى شنده

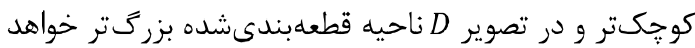
بود. براى توليد نقشه سهَانه، كارى كه انجام شده آن است

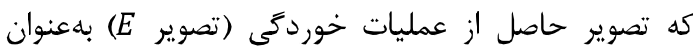

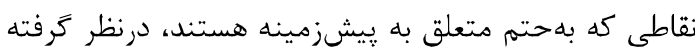

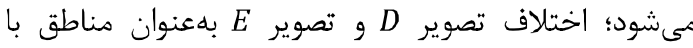
برجسب نامشخص (خاكسترى) و ساير نقاط بلعنوان زمينه (سياه) درنظر كرفته مىشوند. نمايش مراحل كار در بخش بعد، نحوة كار را بهتر نشان خواهد داد.

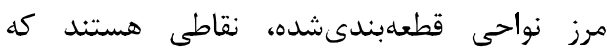
اطمينان صددرصد نسبت به تعلق آنها به دو طبقه وجود ندارد؛ تعيين تعلق آنها به دو طبقه با روشهاى درهمتنيدكى انجام

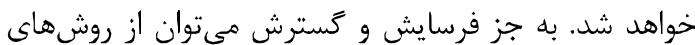
ديكر مرتبط با استخراج دور ناحيه هم استفاده كرد؛ اما برترى

\footnotetext{
' WLbM: Weighted Learning based Matting

${ }^{2}$ Erosion

${ }^{3}$ Dilation
} 
استفاده شده است. خروجى روش قطعهبندى حاصل از

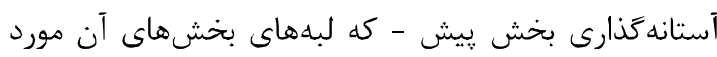

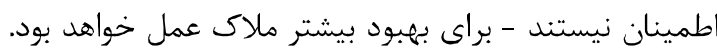
با عمليات سايش و كسترش اين قطعهبندى، نقشأ سهركانه

بلصورت نمايشدادهده در شكل (T- آ هـ) توليد مىشود.

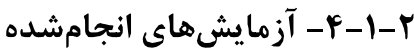

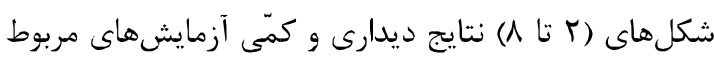
به بهبود استخراج متن از تصوير با روشهاى مختلف را نشان اندان

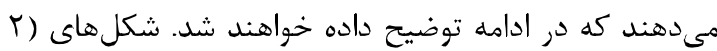

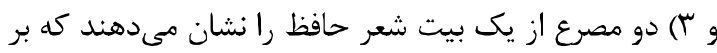
روى زمينههاى مختلف تركيب شدهاند. زيرشكلهاى (الف) و و

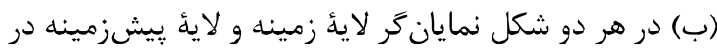

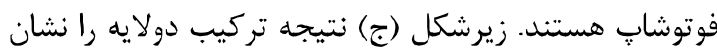

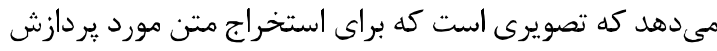

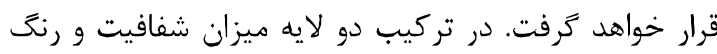
هم مقدارى تغيير داده شده است.

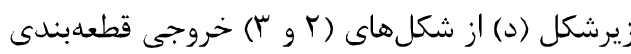

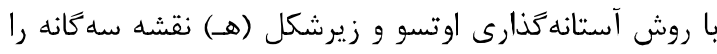

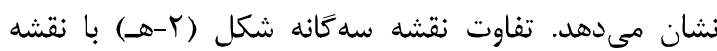

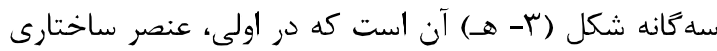

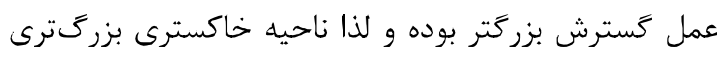

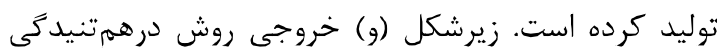

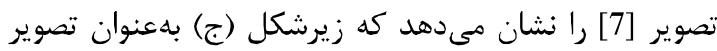

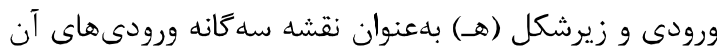
بودهاند. مقدار c در رابطه (ه) براى ائ اين آزمايش، هشتصد

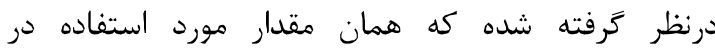
آزمايشهاى نويسندكان [7] است. زيرشكلهاى (ز) و (ح) خروجى روش بر بيشنهادى در در

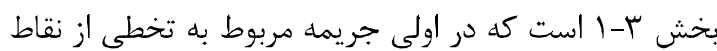

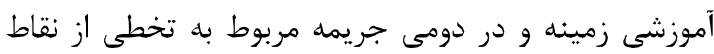

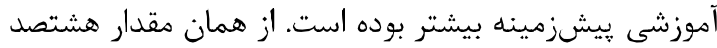

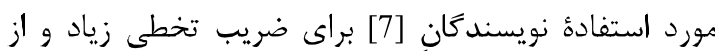
مقدار يك براى ضريب تخطى كم استفاده شده است. بررسى مقدار مناسب ضرايب تخطى در بخش بعد انجام

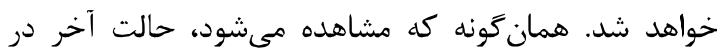

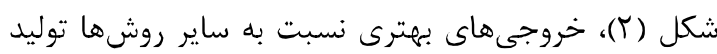
كر منه است. يكى دليل برترى شيؤ درهمتنيدگى تصوير در اين

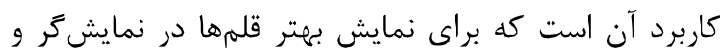

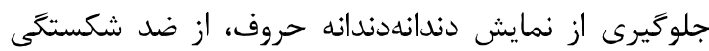

همان كونه كه از شكل (1) مشخص است، در تصوير

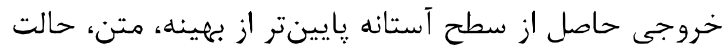
خورده شده دارد و در تصوير حاصل از از سطح آستانه بالاتر از

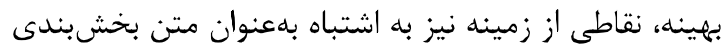

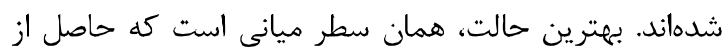

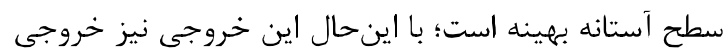

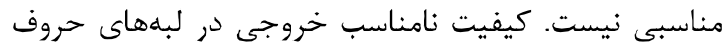

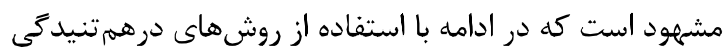
سعى در بهبود آن خواهيم داشت.

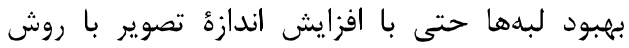

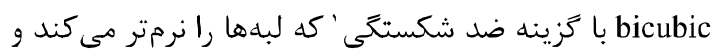

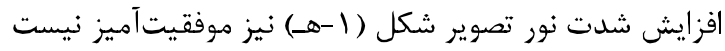

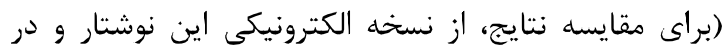

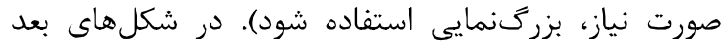
خروجى حاصل از ديكر روشها با با اين خروجى مقايسه خواهد

شد.
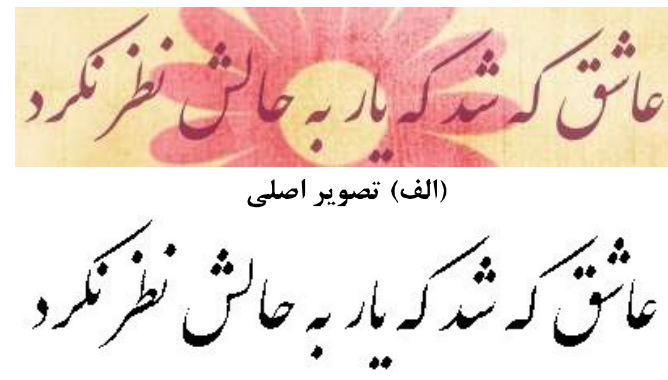

(ب) قطعهبندى با سطح آستانه كمتر از سطح آستانهُ بهينه

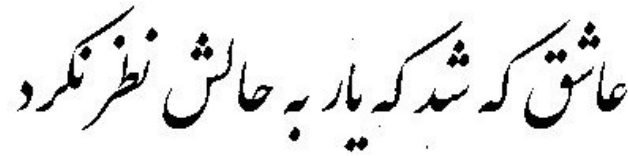

(ج) با سطح آستانةٔ بهينه با روش اوتسو [باء

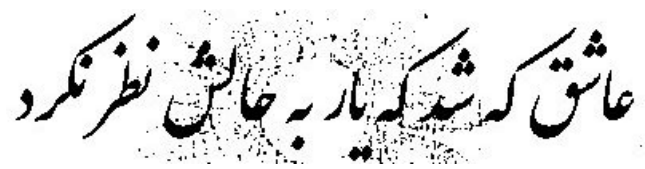

(د) با سطح آستانهُ بيشتر از سطح بهينه

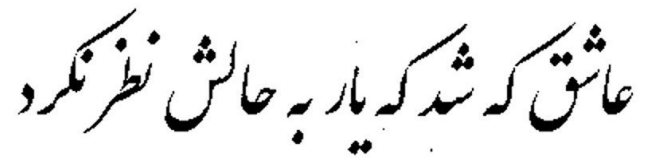

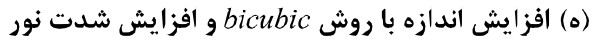

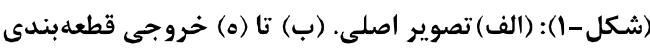

تصوير (الف) با روش آستانهكذارى.

(Figure-1): Image segmentation of (a) with thresholding method.

|-1-1-1 - توليد نقشه سهكانه

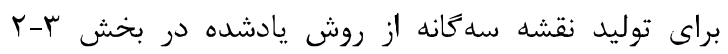

${ }^{1}$ Anti-Aliasing 


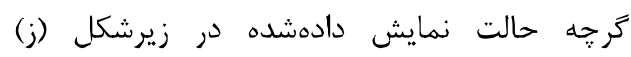

(شكل هاى ץ , و خ) خروجى مناسبى از منظر قطعهبندى نيست

و بهنظر مىرسد كه خروجى بدتر شده و متن حالتى شبيه به

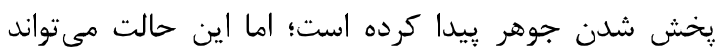

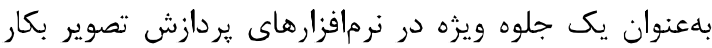

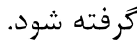

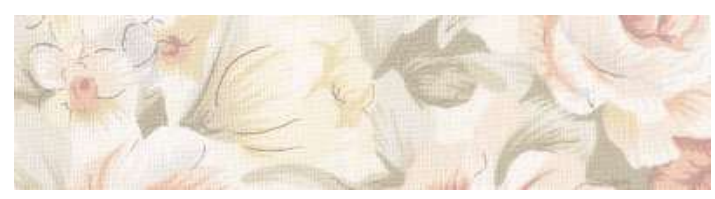

(الف) تصوير زمينه

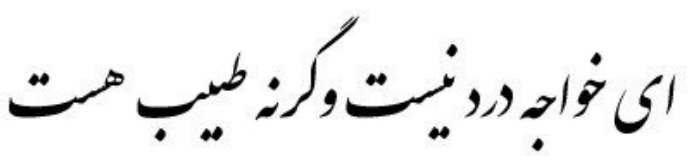

(ب) تصوير پييشزمينه

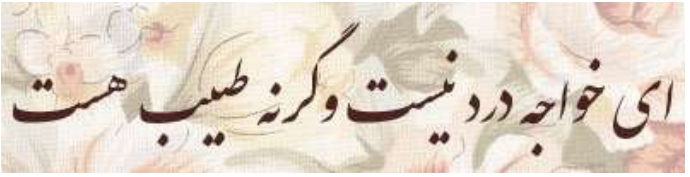

(ج) تصوير مورد بردازش

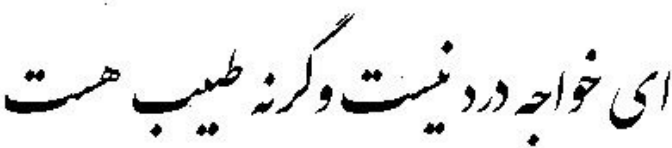

(د) خروجى روش آستانهَذارى

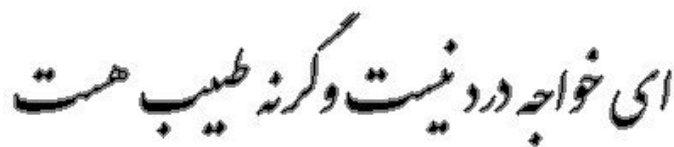

(هـ) نقشه سهكانه با كستر ش كمتر ناحيه مجهول

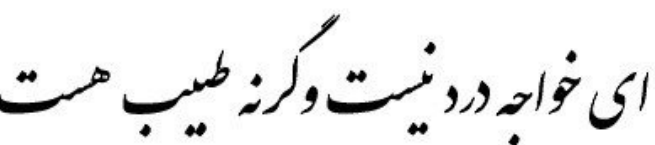

$$
\text { c) }
$$

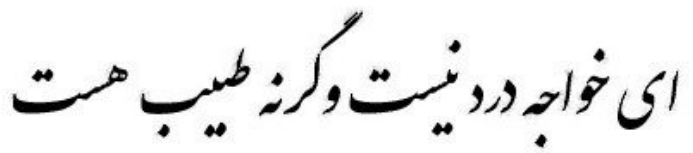

$c_{f}=800$ (ز) خروجى روش بيشنهادى با 1 (ز)

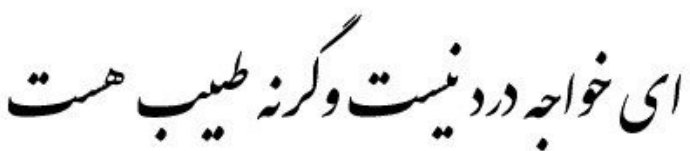

$c_{f}=1, c_{b}=800$ ) خروجى روش ضيشنهادى با (ح)

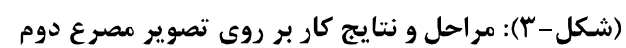

(Figure-3): Intermediate and the final result of the experiments on $2^{\text {ed }}$ hemistich.
استفاده مىشود كه درنتيجه لبهها هموارتر نمايش داده

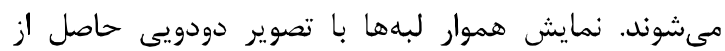

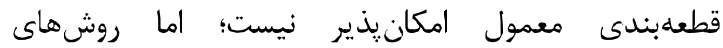

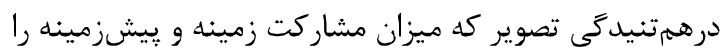

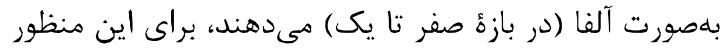
مناسب هستند؛ لذا خروجى اين شيوهها در كاربرد يادشده، جشمنوازتر است.
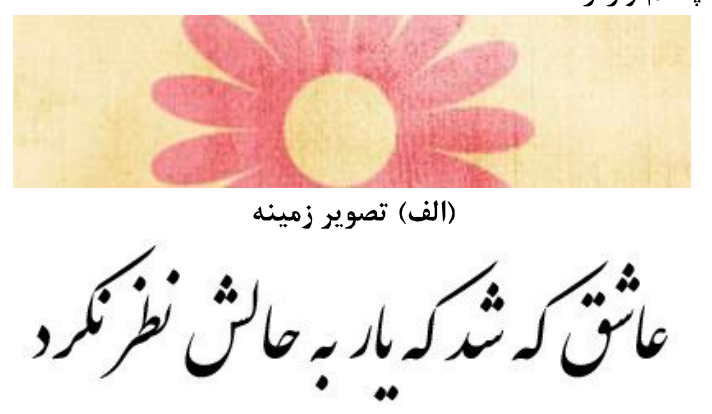
(ب) تصوير קيشزمينه

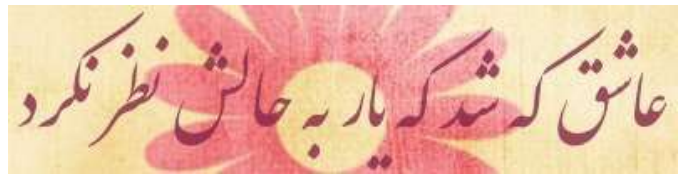
(ج) تصوير مورد يردازش

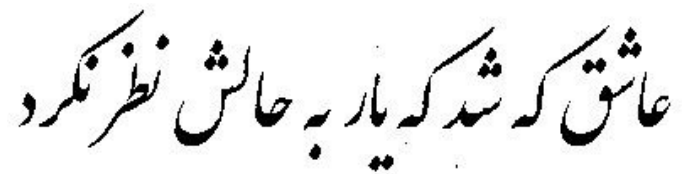
(د) خروجى روش آستانه كذارى
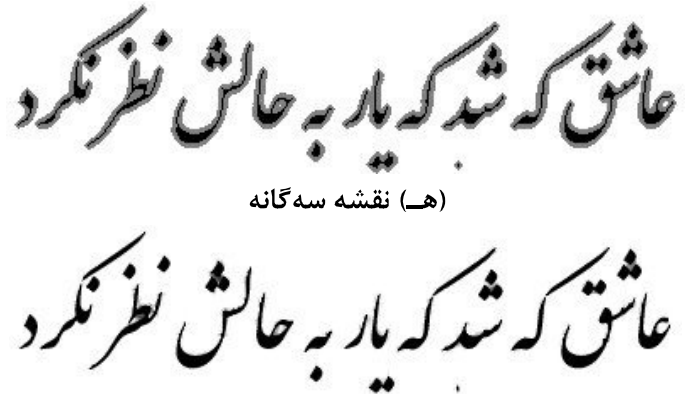
(و) خروجى روش [7] با 800
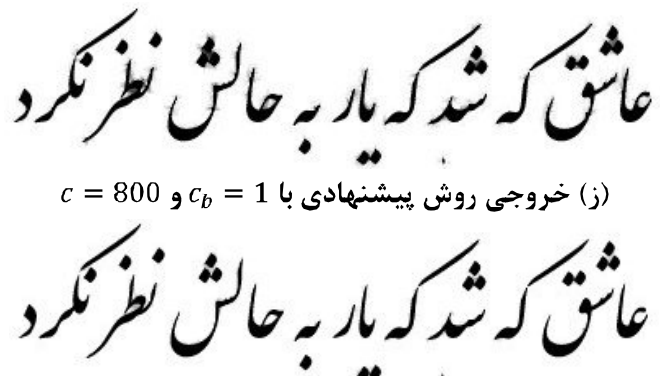

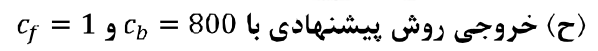

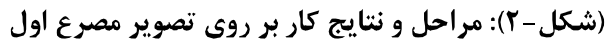

(Figure-2): Intermediate and the final result of the experiments on $1^{\text {th }}$ hemistich. 


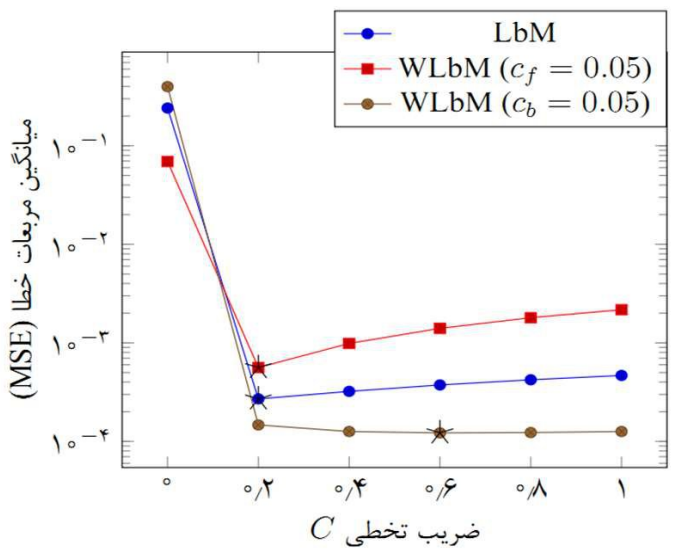

(شكل - ه): مقايسه ميانكين مر بعات خطا بين خروجى روش هاى

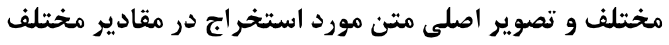

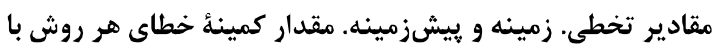

ستاره مشخص شده است. بهتر ين نتيجه متعلق به روش

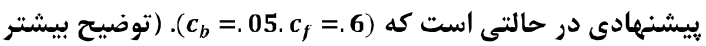

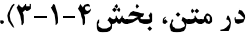

(Figure-5): Comparison of the MSE results on text extraction example. The best results is obtained by the proposed approach (when $c_{b}=0.05 . c_{f}=0.6$ ).

همان گونه كه از نتايج آزمايش ها مشخص است، تغيير

ضرايب مىتواند خروجىهاى متفاوتى را سبب شود. دقيقترشدن كيفيت خروجى متن يا حالت نمايشى از يخش شدگى جوهر روى متن مىتواند با تغيير ضرايب حاصل شود.

\section{P-1-Y - مقادير بهينه ضريب تخطى} آزمايشهاى بخش قبل مشخص كردند كه روش يريشنهادى با تغيير ضرايب تخطى مىتواند نتايج ديدارى و كمّى بهترى

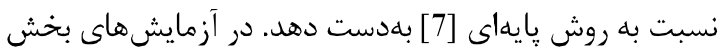
قبل سعى شد از مقدار مورد استفاده توسط نويسندكان [7]

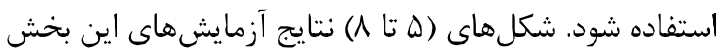
را براى ييداكردن مقادير بهينه ضرايب تخطى در روش ييشنهادى نشان ميدهند كه در ادامه توضيح داده مىشود. از آنجا كه در روش ييشنهلهادى دو ضريب آن داريم كه ضريب ميزان تخطى مقدار آلفاى خروجى روش روى لهى

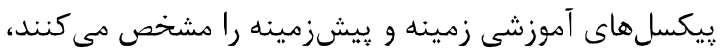

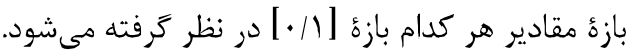
براى ييداكردن مقادير بهينه دو ضريب، هنگامى كه تعداد مقادير ممكن زياد نباشند، مىتوان از جستجوى يرى مريد سراسرى استفاده كرد كه زمانبر است.

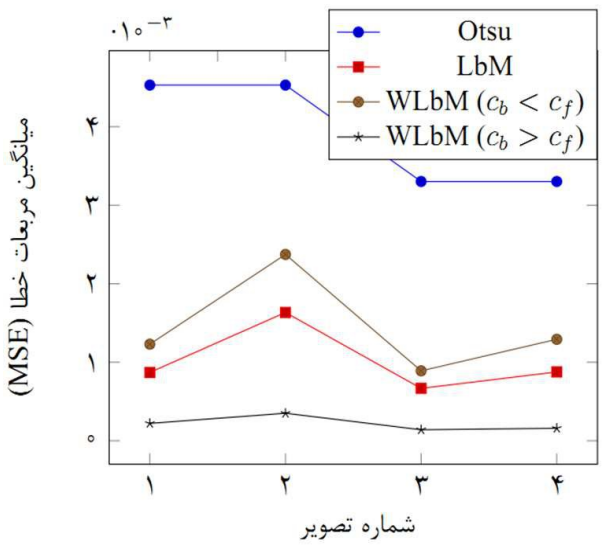

(شكل - F): مقايسه ميانكين مربعات خطا بين خروجى روشهاى

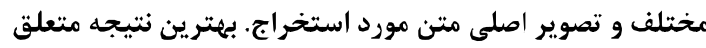

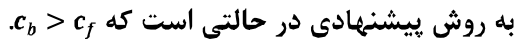
(توضيح بيشتر در متن).

(Figure-4): Comparison of the MSE results on text extraction example. The best results is obtained by the proposed approach (when $c_{b}>c_{f}$ ).

با درنظر گرفتن شكل (ب) بهعنوان خروجى قطعهبندى

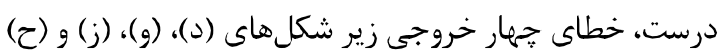
قابل محاسبه است. شكل (f) ميانگين مربعات خطا (رابطه

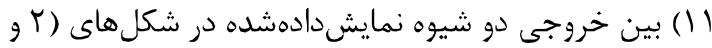
r) و جواب درست را نشان مى دهد. محور X ها نمايان

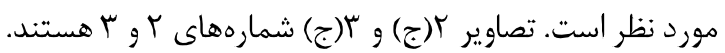
شمارههاى I و f همان تصاوير بالا هستند كه نقشه سه Fانه با ميزان لاكسترشه كمتر ابيشتر از دو تصوير ديخر توليد شده

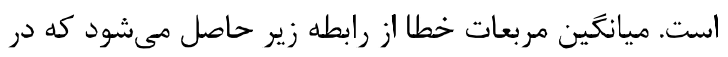

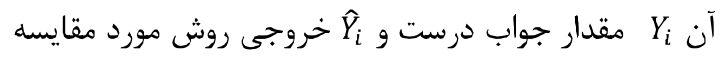
براى ييكسل i أم است:

$M S E=\frac{1}{n} \sum_{i=1}^{n}\left(Y_{i}-\hat{Y}_{i}\right)^{2}$

در كادر راهنماى شكل (Y)، Otsu مشخص كننده روش اوتسو، [7] مشخص كننده روش LbM (Learning based Matting) و مشخص كنندة شيؤ ييشنهادى است كه دو حالت دارد: حالتى كه جريمٔ ميزان تخطى نقاط آموزشى زمينه از

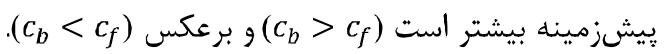

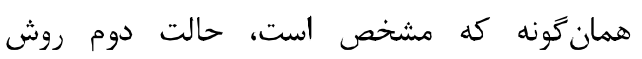
ييشنهادى، خطاى كمترى نسبت به ساير روشها دارد كه منطبق بر نتايج نشاندادهشه بهصورت بصرى در شكلهاى

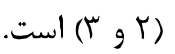



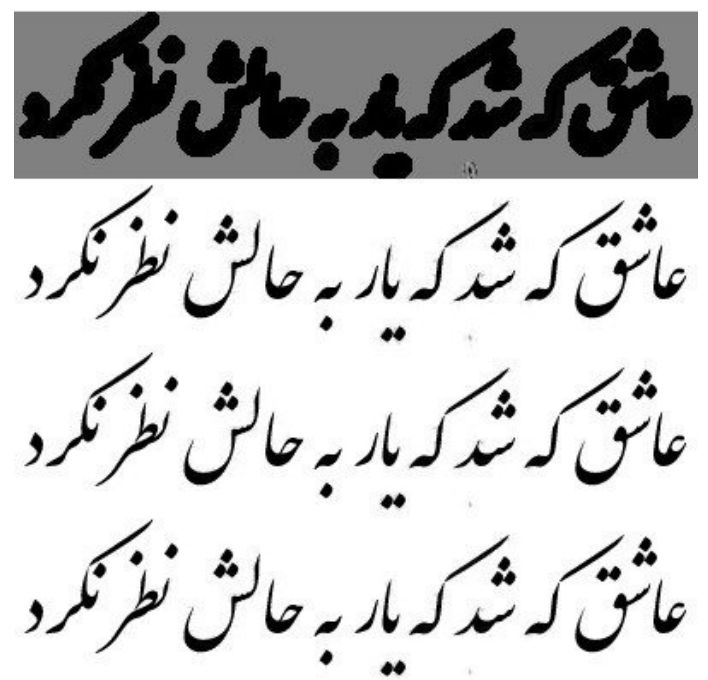

(شكل-1): از بالا به بايين: خروجى (مناسب) روش بيشنهادى با

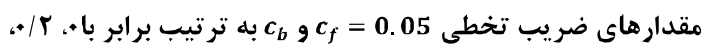

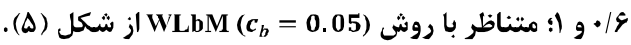
(Figure-8): From top to bottom: The results of the proposed method with $c_{f}=0.05$ and $c_{b}$ equals to $0,0.2,0.6$ and 1 , respectively.

براى روش پيشنهادى، مقدار يك پارامتر هـ • • و براى

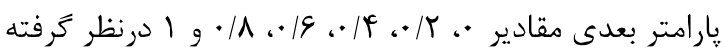
شد. بر طبق نتايج حاصلشده، كمترين خطا مربوط به حالت (c.6.0.05) بهينهسازى براى ييداكردن مقادير بهينه اين يارامترها از جمله كارهاى آينده اين يروهش است. روش ساده يادشده، نشان داد برد كه با انتخاب مقادير مناسب براى ضرايب تخطى زمينه و ييشزمينه، روش ييشنهادى مى تواند خطاى كمترى نسبت به روش اصلى بلهدست دهد.

تصاوير خروجى متناظر با مقادير تخطى برابر با •، ك/ •،

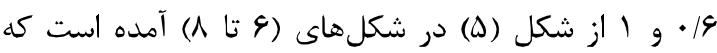

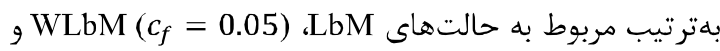
از شكل (هLbM (c) $\left.c_{b}=0.05\right)$ مربوط به هر حالت نمودار با ستاره مشخص شده است. هر سه مورد در وضعيت مقدار تخطى برابر با صفر، بيشترين خطا را داشتهاند. در دو حالت نخست، مقدار خطا با افزايش مقدار ضريب تخطى افزايش ييدا كرده است (به جز در مقدار صفر). اما در حالت سوم - WLbM ( مقدار خطا سير نزولى دارد و يس از آن با افزايش مواجه

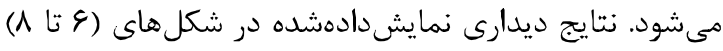

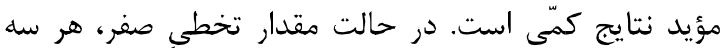
روش ضعيفترين خروجىها را دارند. سطر سوم نتايج روش

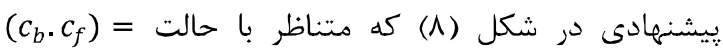
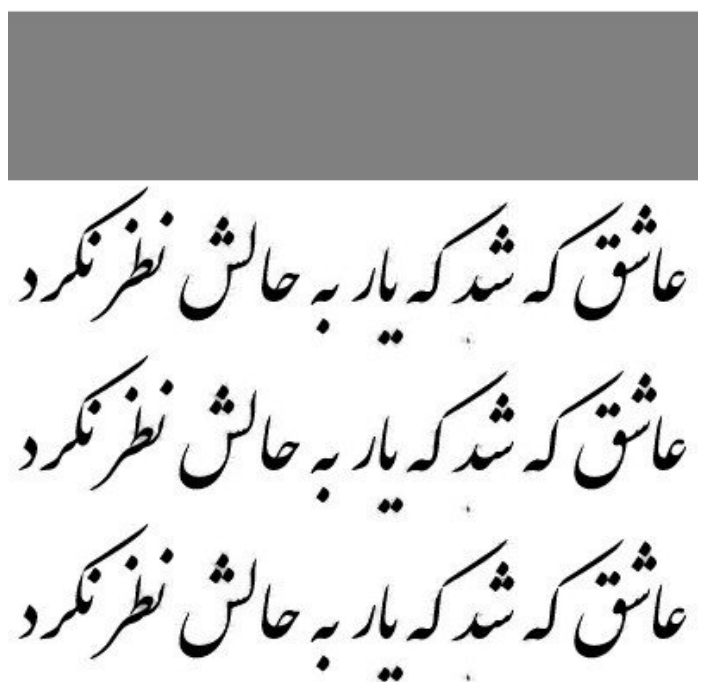

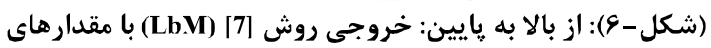

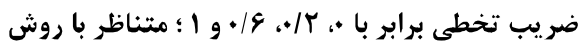

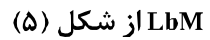

(Figure-6): From top to bottom: The results of the LbM method [7] with $C$ equals to $0,0.2,0.6$ and 1 .

با ثابت درنظرگرفتن يك ضريب و كمتركردن تعداد يارامترها، هم زمانٍ موردنياز، كمتر خواهد شد و هم نتايج بلراحتى با روش اصلى - كه يك ضريب تخطى دارهم دارد - قابل مقايسه خواهد بود. در آزمايشهاى نشاندادادشده در شكل

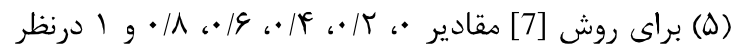

كرفته شد.
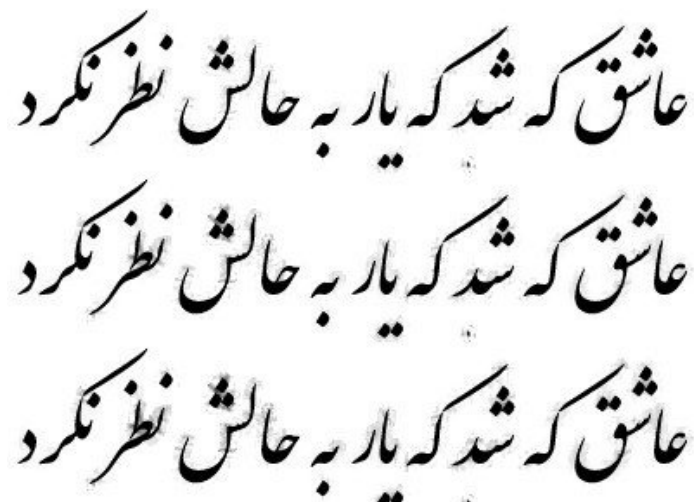

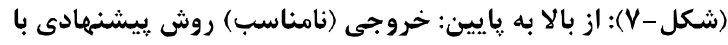

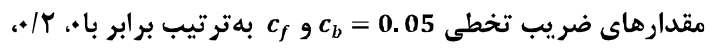

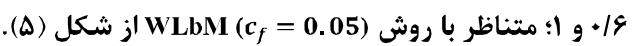

(Figure-7): From top to bottom: The results of the proposed method with $c_{b}=0.05$ and $c_{f}$ equals to $0,0.2,0.6$ and 1 , respectively. 
كه بخش داخلىتر رى بلهدرستى شناسايى شده است.

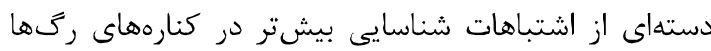

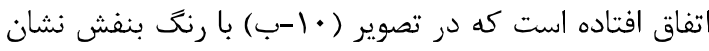

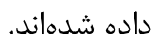
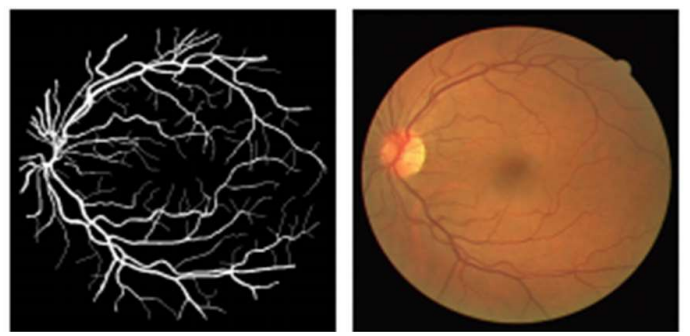

(الف) تصوير اول از مجموعه DRIVE

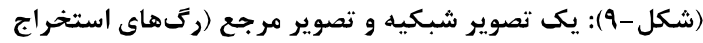

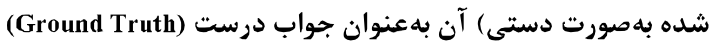

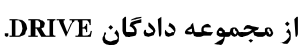

(Figure-9): (a) First retinal image from DRIVE dataset, (b) the hand labelled "truth" image.
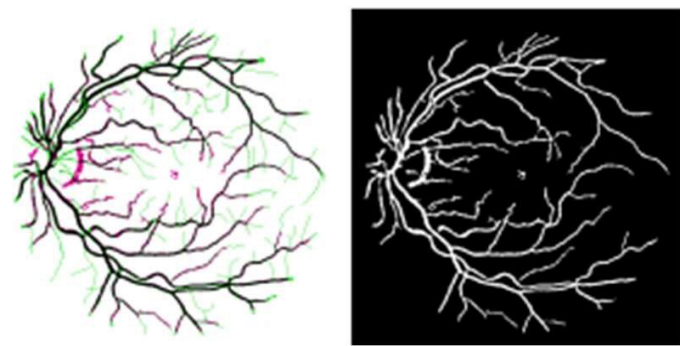

(الف) خروجى روش [17] (ب) خطاى روش [17] (شكل-+1): يكى روش استخر اج رتى و خطاى شناسايى آن. (الف) خروجى طبقهبندى با روش استخراج موجك [17] بر روى شكل 9(الف). (ب) نمايش خطاى روش، نواحى سياه و سفيد رنى،

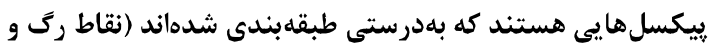

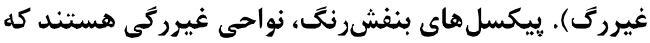

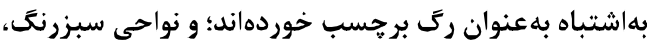

ركىهايى هستند كه بهاشتباه تشخيص داده نشدهاند.

(Figure-10): (a) Vessel segmented image of [17|. In (b) the black and white pixels are those pixeles that are classified correctly; Purple pixels show missclassified pixels labled as 'vessel' and Green pixels demonstrate vessel regions that labled as 'non vessel'.

نحوة كار، مشابه روش مورد استفاده در بخش استخراج

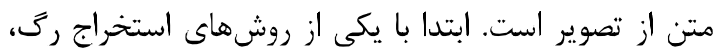

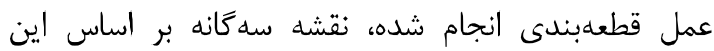
قطعبندى توليد و با روش درهمتنيدگى تصوير، روى نواحى إنى

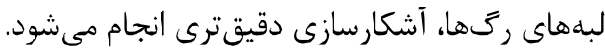

(0.6.0.05) است، داراى كمترين خطاست كه مقايسه بصرى

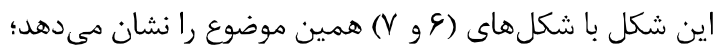
لذا شيؤ ييشنهادى در اين كاربرد مى تواند نتايج بهترى نسبت به شيوء اصلى توليد كند.

\section{Y-F- دقيقتركردن نتايج استخراج ركهاى جشم}

بهنوان كاربرد دوم، مسأله دقيقتركردن استخراج ركهاى

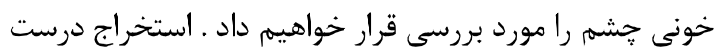

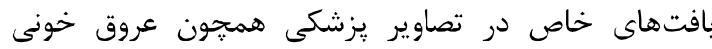

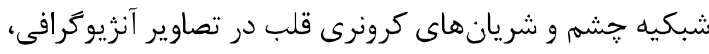

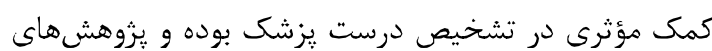

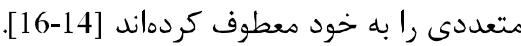
روشهاى مرسومى كه در حوزة استخراج ركهاى درداى

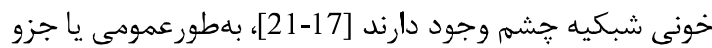

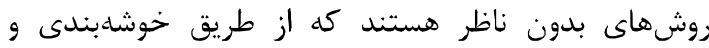

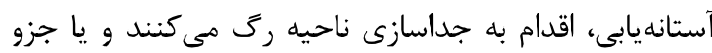
روشهاى با ناظر هستند كه از طبقهبندهايى همجيون ماشين

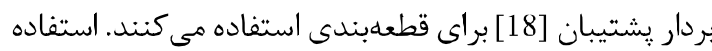

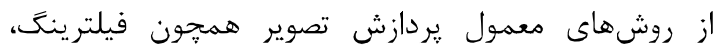

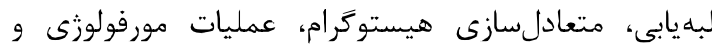
تبديل موجك [17] هم در اين حوزه مرسوم است. با توجه به به ميه اينكه هدف اين مقاله، ييشنهاد يك روش استخراج رك نيست،

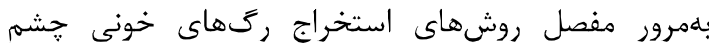

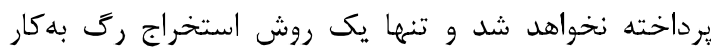
كرفته شده و نتايج آن بهبود داده خواهد شد.

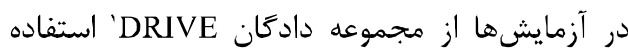

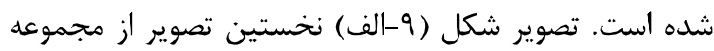

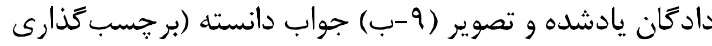

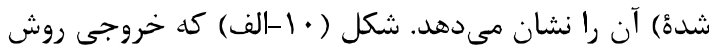

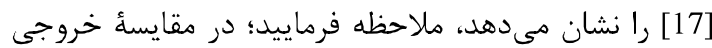
اين شيوه با تصوير مرجع متناظر با آن شكل (9-ب) مشاهده

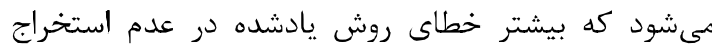

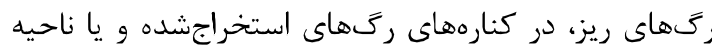

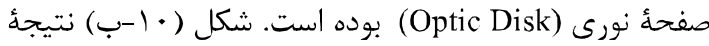

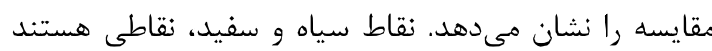

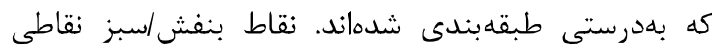

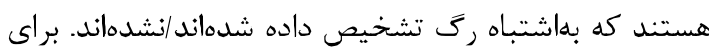

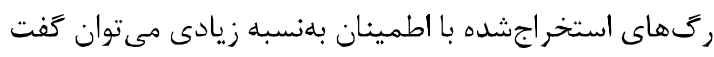

${ }^{1}$ http://www.isi.uu.nl/Research/Databases/DRIVE/ 


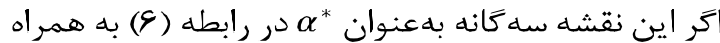

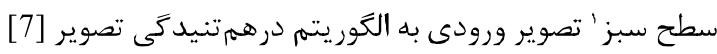
داده شده و م بهينه دحاسبه شود، ميتوان اميدوار بود كه

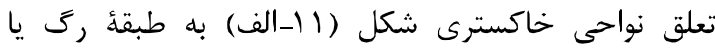
غيررى با دقت بيشترى مشخص شود. آلفاى دحاسبهشده كه در شكل (1ا-ب) نشان داده شده است، مقادير بين صفر و

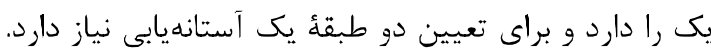

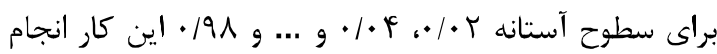
شده و بهترين سطح آستانه براى هر تصوير مشخص شده

شكلهاى (r ا و rا) نتيجه دقيقتركردن روش استخراج رى حاصل از روش [17] را نشان مىدهند.
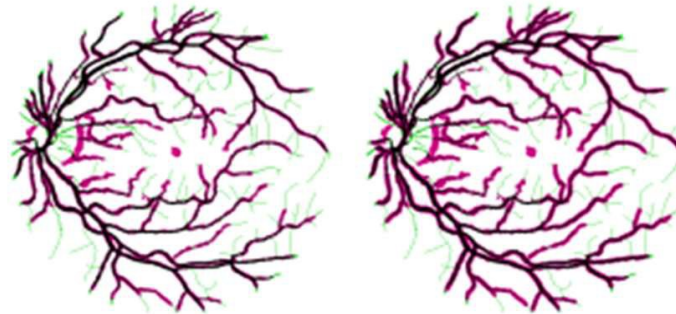

(ب) سطح آستانه: • (ץ/•

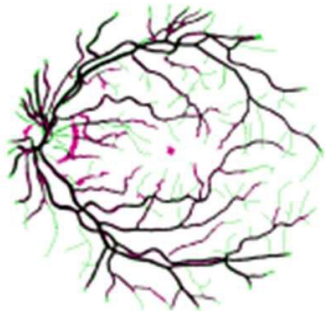

(الف) سطح آستانه: •1/·

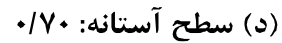
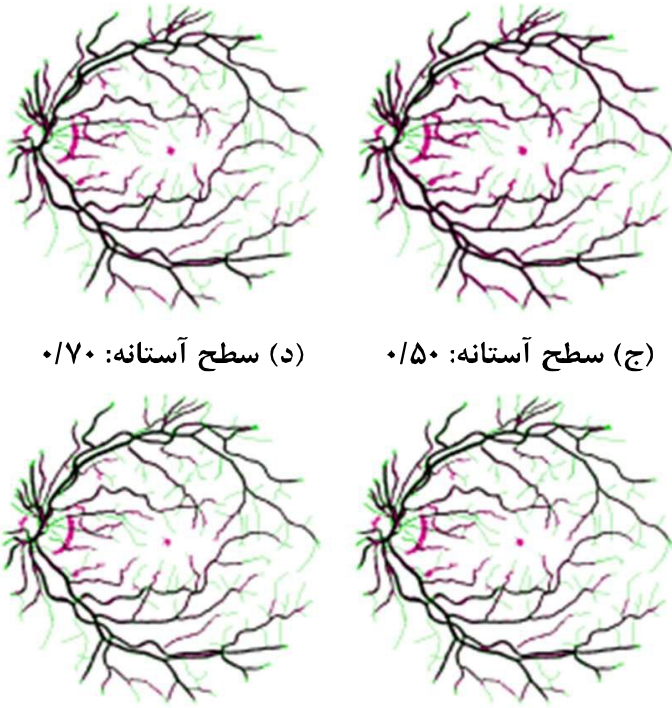

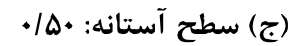

(و) سطح آستانه: 191.

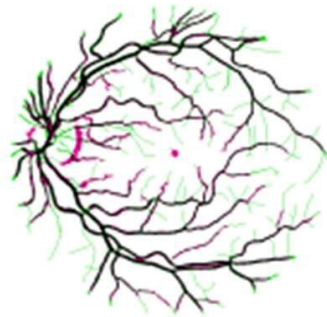

(0) سطح آستانه: • •19/. (شكل - Ir): خروجى بر اساس سطوح مختلف آستان آستانه روى آلفاى آستان:

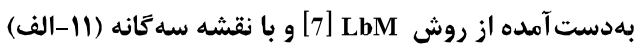

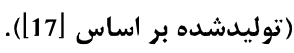

(Figure-12): Enhancement of retinal vessel segmentation [17] with matting method [7] on different thresholding values of alpha.
|

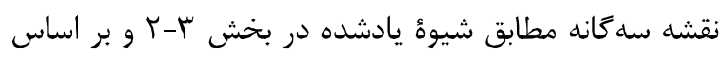

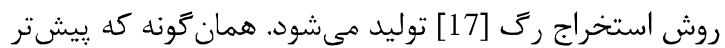

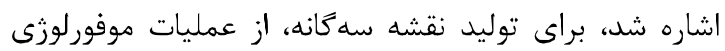
فرسايش و كَترش روى نواحى استخراجشده استفاده

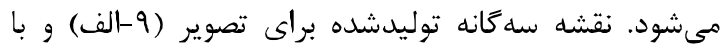

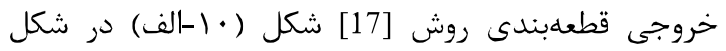
(11 (1الف) نشان داده شده است. r-r-r-r-r آزمايشهاى انجامشده براى هر تصوير از مجموعه دادكان، نقشه سه گانهُ ايجادشده،

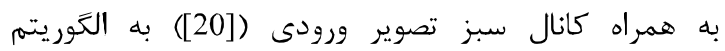
درهمتنيدگى تصوير داده مى بهود.

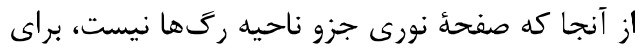

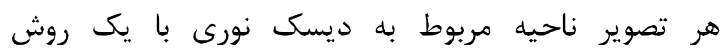

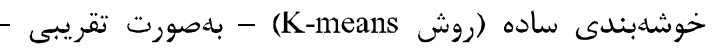
شناسايى و از خروجى حذف شده است. بلهمنظور يرهيز از تفاوت خروجى خوشهبندى در اجراهاى متعدد، اين عمل يكبار براى هر تصوير انجام شده و ناحيه مربوط به صفحئ

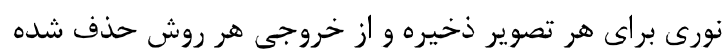

عمليات بالا براى هر تصوير از مجموعه دادكان مورد

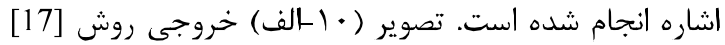

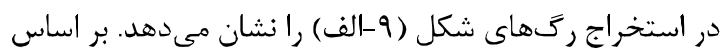
اين خروجى و مطابق با روش ييشنههادى يادشده در بخش قربل

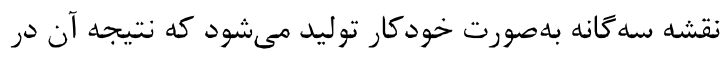
شكل (11 الف) نشان داده شله است.

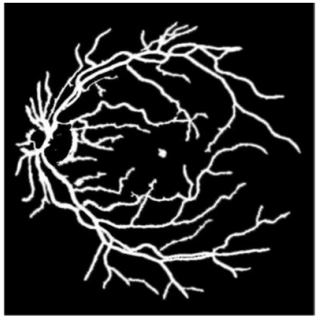

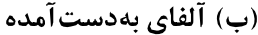

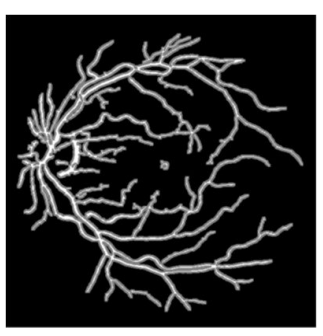

(الف) نقشه سهكانه
(شكل -11): (الف) نقشه سهكانه توليدشده براى شكل (مانه (•آ-الف)،

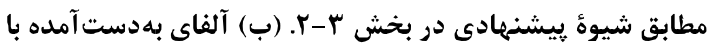

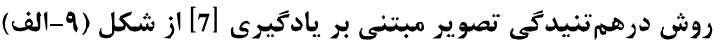

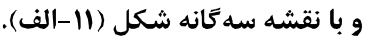

(Figure-11): Trimap and the alpha image produced by the matting method $[7]$.

'در بسيارى از يزوهشهاى انجام شده در حوزه شنا سايى ركى و

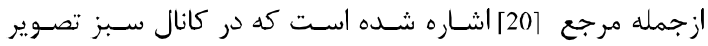

مربوط به شـــبكيه، نســبت به دو كانال رنكى قرمز و آبى، تمايز بيشترى بين رى و زمينه وجود دارد.

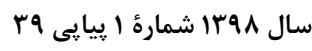


(جدول -1): ارزيابى مبتنى بر معيار صحت. ستون دوم: روش [17]،

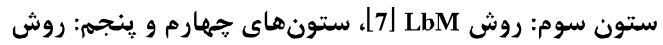
ويشنهادى WLbM (بخش Y-Y-1) با ضر ايب مختلف براى زمينه و ييشزمينه

(Table-1): Performance comparisons based on Accuracy. First column: Image Number in DRIVE dataset, second column: [17], third column: LbM [7], the last two columns are the proposed WLbM method with different values for $\left(C_{b} \cdot C_{f}\right)$. (Sec. 1-3).

\begin{tabular}{|c|c|c|c|c|}
\hline \multicolumn{3}{|c|}{ ضرايب جر يمه زمينه و بيشز مينه } & \multicolumn{2}{|c|}{ جة: 3: روش مرجع } \\
\hline$(1,800)$ & $(800,1)$ & 800 & [17] & \\
\hline 0.943 & 0.946 & 0.943 & 0.944 & 1 \\
\hline 0.949 & 0.951 & 0.950 & 0.949 & r \\
\hline 0.941 & 0.942 & 0.942 & 0.941 & r \\
\hline 0.946 & 0.948 & 0.946 & 0.946 & f \\
\hline 0.952 & 0.952 & 0.952 & 0.953 & $\Delta$ \\
\hline 0.938 & 0.938 & 0.938 & 0.938 & \& \\
\hline 0.945 & 0.948 & 0.946 & 0.946 & V \\
\hline 0.929 & 0.933 & 0.930 & 0.930 & $\wedge$ \\
\hline 0.938 & 0.938 & 0.938 & 0.939 & 9 \\
\hline 0.947 & 0.950 & 0.947 & 0.948 & 1. \\
\hline 0.941 & 0.946 & 0.941 & 0.941 & 11 \\
\hline 0.946 & 0.949 & 0.946 & 0.946 & ir \\
\hline 0.931 & 0.930 & 0.931 & 0.931 & Ir \\
\hline 0.942 & 0.948 & 0.942 & 0.943 & if \\
\hline 0.933 & 0.933 & 0.934 & 0.935 & 10 \\
\hline 0.943 & 0.946 & 0.944 & 0.944 & 19 \\
\hline 0.947 & 0.951 & 0.948 & 0.948 & IV \\
\hline 0.948 & 0.949 & 0.948 & 0.947 & 11 \\
\hline 0.944 & 0.944 & 0.944 & 0.943 & 19 \\
\hline 0.936 & 0.937 & 0.936 & 0.936 & $r \cdot$ \\
\hline 0.942 & 0.944 & 0.942 & 0.942 & يانكير \\
\hline
\end{tabular}

همان گونه كه انتظار مىرود، هنحامى كه سطح آستانه

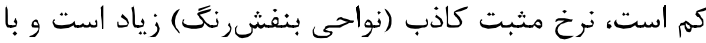

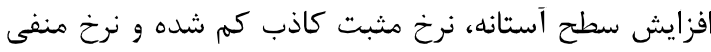

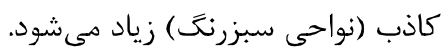

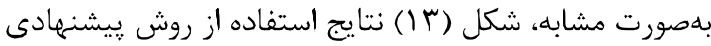

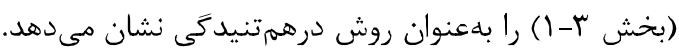

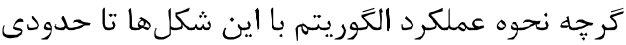
مشخص مىشود، ولى براى نتيجه كَيرى دقيق بايد به نتايج

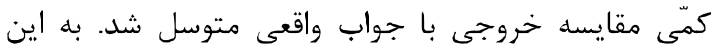
منظور خروجى حاصل از آستانهيابى در سطوح مختلف بابل

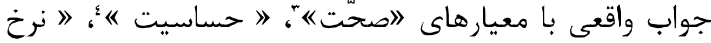

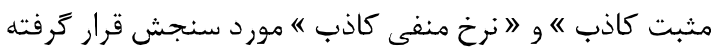

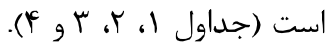
بهترين جواب در هر سطر با زمينه خاكسترى رنت

\footnotetext{
${ }^{3}$ Accuracy

${ }^{4}$ Sensitivity, true positive rate, or the recall
}
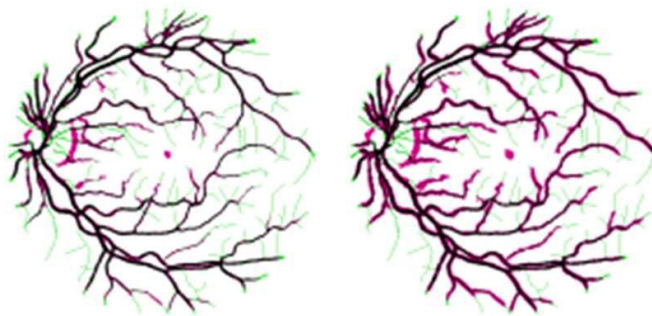

(ب) سطح آستانه: • •|+ (الف) سطح آستانه:+1/+
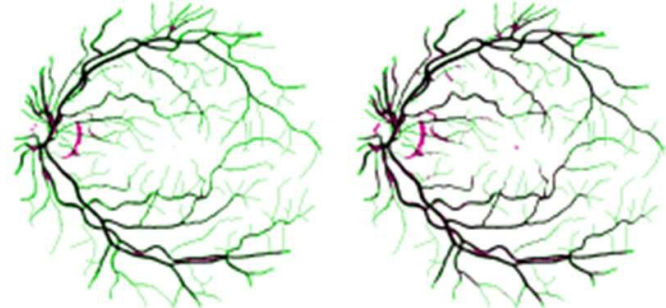

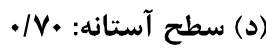
(ج) سطح آستانه: •ه|•
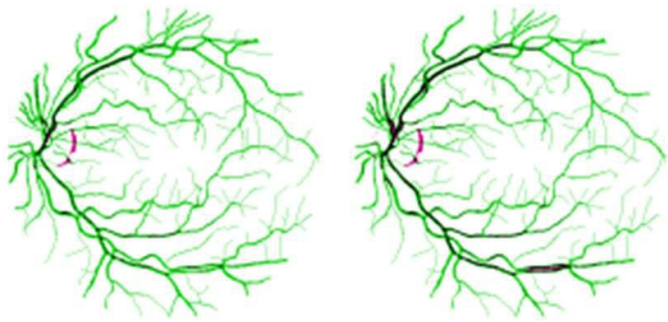

(و) سطح آستانه: 191.

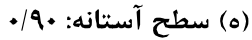

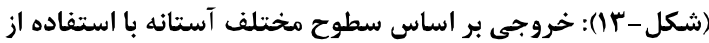

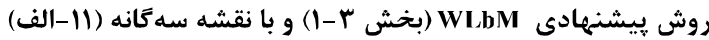
(توليد شده بر اساس |17]).

(Figure-13): Enhancement of retinal vessel segmentation [17] with the proposed matting method on different thresholding values of alpha.

در اين دو شكل، نقشه سهكَانه مبتنى بر روش [17]

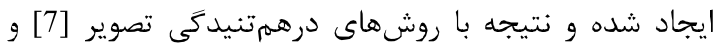

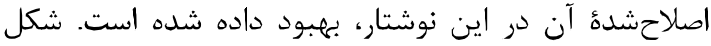

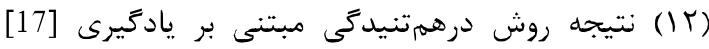

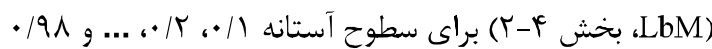
را نشان مى دهد. نخستين تصوير كه نمايش داده شده، مربوط به سطح آستانه / / است. در هر تصوير، نواحى سياه و سفيدرنخ، بيكسلهايى

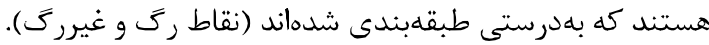
يِيكسلهاى بنفشرنغ، نواحى غير

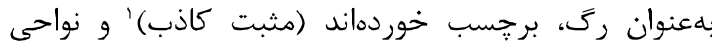
سبزرنك، رك هايى هستند كه بعاشتباه تشخيص داده نشدهاند

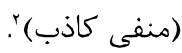

${ }^{1}$ False Positive

${ }^{2}$ False Negative 
(جدول - (ب): ارزيابى مبتنى بر معيار نرخ مثبت كاذب.

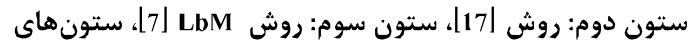

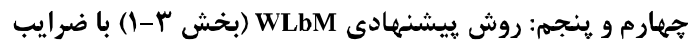

$$
\text { مختلف براى زمينه و هيش جيشزمينه. }
$$

(Table-3): Performance comparisons based on False Positive Rate. First column: Image Number in DRIVE dataset, second column: [17], third column: LbM [7] the last two columns are the proposed WLbM method with different values for $\left(C_{b} \cdot C_{f}\right)$.

\begin{tabular}{|c|c|c|c|c|}
\hline \multicolumn{3}{|c|}{ ضر ايب جريمه زمينه و بيشز زمينه } & \multicolumn{2}{|c|}{ حر: روش مرجع } \\
\hline$(1,800)$ & $(800,1)$ & 800 & [17] & \\
\hline 0.031 & 0.023 & 0.031 & 0.029 & T \\
\hline 0.017 & 0.017 & 0.018 & 0.015 & 1 \\
\hline 0.024 & 0.025 & 0.027 & 0.023 & r \\
\hline 0.023 & 0.016 & 0.022 & 0.022 & r \\
\hline 0.024 & 0.019 & 0.023 & 0.022 & $\Delta$ \\
\hline 0.021 & 0.019 & 0.021 & 0.021 & $\Leftrightarrow$ \\
\hline 0.033 & 0.021 & 0.032 & 0.032 & v \\
\hline 0.049 & 0.029 & 0.048 & 0.047 & $\wedge$ \\
\hline 0.029 & 0.023 & 0.028 & 0.027 & $q$ \\
\hline 0.032 & 0.021 & 0.031 & 0.031 & 1. \\
\hline 0.029 & 0.021 & 0.029 & 0.028 & 11 \\
\hline 0.029 & 0.021 & 0.028 & 0.028 & it \\
\hline 0.022 & 0.023 & 0.023 & 0.021 & r \\
\hline 0.037 & 0.020 & 0.037 & 0.036 & If \\
\hline 0.041 & 0.025 & 0.040 & 0.039 & 10 \\
\hline 0.029 & 0.021 & 0.028 & 0.027 & 19 \\
\hline 0.030 & 0.021 & 0.029 & 0.028 & IV \\
\hline 0.020 & 0.020 & 0.021 & 0.018 & 11 \\
\hline 0.020 & 0.019 & 0.021 & 0.019 & 19 \\
\hline 0.024 & 0.021 & 0.023 & 0.022 & r. \\
\hline 0.028 & 0.021 & 0.028 & 0.027 & يn \\
\hline
\end{tabular}

ستون سوم نتيجهُ استفاده از روش درهمتنيدگى تصوير [7] روى جواب [17] را نشان مىدهد. ستونهاى جهارم و

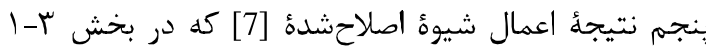
ييشنهاد شده بود و با مقادير (800.1) l, بهنوان ضرايب زمينه و ويشزميشه

$$
\text { نشان مى دهند. }
$$

در مورد معيارهاى صحت و حساسيت، مقادير بيشتر و

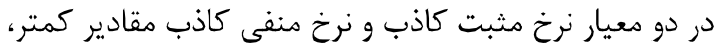
بهتربودن نتيجه را مشخص مى كنند. همان گونه كه مشاهده مىشود با اين مجموعه دادگًان، در بيشتر معيارهاى سنجش، در حالت ميانخين، يكى از نسخدهاى روش ييشنهادى مبتنى مئى بر درهمتنيدگى تصوير حائز بهترين عملكرد بوده است. در معيارهاى صحت، نرخ مثبت كاذب و نرخ منفى كاذب، روش ييشنهادى نسبت به روش [7] كاراتر بوده است.
مشخص شده است. سطر آخر هر جدول نيز ميانگين نتايج براى هر ستون را نشان ميدهد كه در اينجا نيز بهترين مورد هرد با زمينه خاكسترى مشخص شده است.

(جدول - Y): ارزيابى مبتنى بر معيار حساسيت. ستون دوم: روش

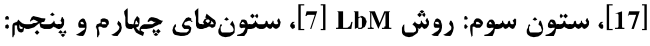

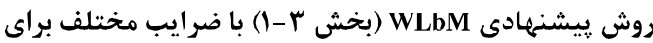

زمينه و وييشزمينه.

(Table-2): Performance comparisons based on Sensitivity. First column: Image Number in DRIVE dataset, second column: [17], third column: LbM [7], the last two columns are the proposed WLbM method with different values for $\left(C_{b} \cdot C_{f}\right)$.

\begin{tabular}{|c|c|c|c|c|}
\hline \multicolumn{3}{|c|}{ ضرايب جريمه زمينه و بيش زمينه } & \multicolumn{2}{|c|}{ ه: 3: روش مرجع } \\
\hline$(1,800)$ & $(800,1)$ & 800 & {$[17]$} & \\
\hline 0.769 & 0.738 & 0.767 & 0.758 & 1 \\
\hline 0.755 & 0.766 & 0.765 & 0.742 & r \\
\hline 0.710 & 0.717 & 0.731 & 0.703 & r \\
\hline 0.728 & 0.701 & 0.727 & 0.726 & f \\
\hline 0.773 & 0.742 & 0.769 & 0.762 & $\Delta$ \\
\hline 0.673 & 0.659 & 0.671 & 0.671 & 4 \\
\hline 0.759 & 0.680 & 0.758 & 0.756 & v \\
\hline 0.724 & 0.580 & 0.720 & 0.717 & $\wedge$ \\
\hline 0.688 & 0.641 & 0.684 & 0.680 & 9 \\
\hline 0.769 & 0.700 & 0.767 & 0.763 & $1 \cdot$ \\
\hline 0.719 & 0.701 & 0.721 & 0.711 & 11 \\
\hline 0.754 & 0.725 & 0.751 & 0.746 & IT \\
\hline 0.656 & 0.653 & 0.665 & 0.651 & r \\
\hline 0.774 & 0.685 & 0.772 & 0.768 & if \\
\hline 0.720 & 0.586 & 0.719 & 0.717 & 10 \\
\hline 0.747 & 0.712 & 0.745 & 0.739 & 19 \\
\hline 0.757 & 0.721 & 0.755 & 0.751 & IV \\
\hline 0.738 & 0.748 & 0.745 & 0.718 & 11 \\
\hline 0.726 & 0.724 & 0.735 & 0.718 & 19 \\
\hline 0.677 & 0.664 & 0.675 & 0.669 & $r$. \\
\hline 0.731 & 0.692 & 0.732 & 0.723 & يالني \\
\hline
\end{tabular}
(Sec. 1-3).

اگر TP (True Positive) معرف تعداد مثبت صادق، FP (False معرف تعداد منفى صادق، TN (True Negative) FN (False Negative) معرف تعداد مثبت كاذب و Positive) معرف تعداد منفى كاذب باشد، معيار صحت بر اساس رابطه مدرب ge $\quad A C c=(T P+T N) /(T P+T N+F P+F N)$

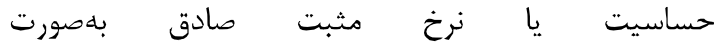
TPR $=T P /(T P+F N)$

در اين مقايسهها بهترين حالت روش بيشنهادى با بالت جواب اوليه مقايسه شده است. ستون نخست، شماره تصوير از

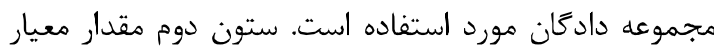
خروجى روش [17] در مقايسه با جواب دانسته را مورد اسنان مى دهد. 
و بايد يك روش آستانهيابى خودكار استفاده شود. روش Leave-One-Out زيادى همانند نتايج يادشده بودند.

\section{ه- نتيجه گيرى}

در ساليان اخير، روشهاى درهمتنيدكى تصوير كه با تعامل با كاربر به قطعلبندى ظريف تصوير مىيردازند، توجهات زيادى را به خود معطوف كردهاند. يكى از روشهاى مطرح در اين

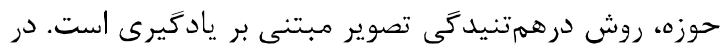

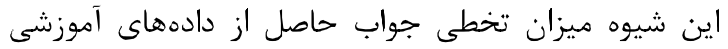

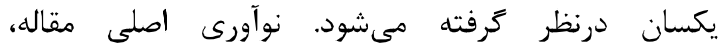
درنظركرفتن وزن متفاوت براى دادههاى آموزشى متعلق به دو دوري

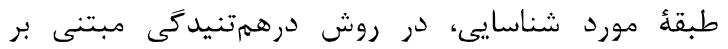
يادكيرى است. يك شيوه خودكار توليد نقشه سهُانه نيز معرفى شد كه با عمليات مورفولوزى مناسب، نقشه سه كانه بر

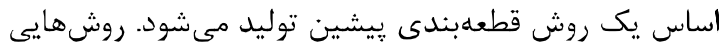
نيز براى קيداكردن مقادير بهينه ضرايب تخطى و حد آستانه

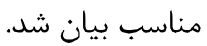
بهمنظور مقايسهُ شيوء اصلاحى با روش اصلى، هر دو

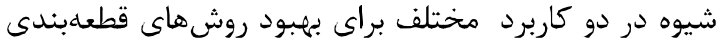

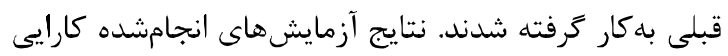

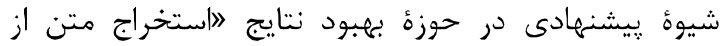

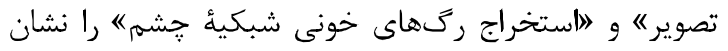
دادند. در كاربرد دقيقتركردن كيفيت خروجى متن مستخرج از تصوير، ضرايب تخطى نامناسب، منجر به توليد حالت يخششدكى جوهر روى متن شد كه مئواند به بهعنوان جلوههاى ويره در نرمافزارهايى همجٍون فوتوشاي به كار زرفته

\section{6- References}

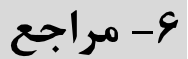

[1] J. Wang and M. F. Cohen, "Image and video matting: A survey," Found. Trends. Comput. Graph. Vis., vol.3, pp.97-175, Jan. 2007.

[2] J. Johnson, D. Rajan, and H. Cholakkal, "Sparse codes as alpha matte," in $B M V C$, BMVA Press, 2014.

[3] Q. Chen, D. Li, and C.-K. Tang, "KNN mat-ting," Pattern Analysis and Machine Intelli-gence, IEEE Transactions on, vol.35, pp.2175-2188,Sept 2013.

[4] J. Gao, M. Paul, and J. Liu, "The image mat-ting method with regularized matte," IEEE Computer Society in ICME, , pp.550-555, 2012.
(جدول - P): ارزيابى مبتنى بر معيار نرخ منفى كاذب. ستون دوم:

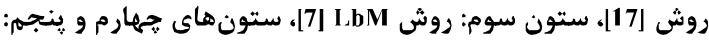

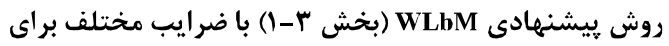

$$
\text { زمينه و وِيشزمينه }
$$

(Table-4): Performance comparisons based on False Negative Rate. First column: Image Number in DRIVE dataset, second column: [17], third column: LbM [7], the last two columns are the proposed WLbM method with different values for $\left(C_{b} \cdot C_{f}\right)$.

\begin{tabular}{|c|c|c|c|c|}
\hline \multicolumn{3}{|c|}{ ضرايب جريمه زمينه و بيشزمينه } & \multicolumn{2}{|c|}{ هُ: 3، روش مرجع } \\
\hline$(1,800)$ & $(800,1)$ & 800 & {$[17]$} & \\
\hline 0.034 & 0.039 & 0.034 & 0.036 & 1 \\
\hline 0.042 & 0.040 & 0.041 & 0.045 & r \\
\hline 0.043 & 0.042 & 0.040 & 0.044 & r \\
\hline 0.040 & 0.043 & 0.040 & 0.040 & c \\
\hline 0.030 & 0.034 & 0.031 & 0.032 & $\Delta$ \\
\hline 0.051 & 0.053 & 0.051 & 0.051 & $\varepsilon$ \\
\hline 0.028 & 0.037 & 0.028 & 0.028 & v \\
\hline 0.030 & 0.045 & 0.030 & 0.031 & $\wedge$ \\
\hline 0.041 & 0.048 & 0.042 & 0.042 & 9 \\
\hline 0.027 & 0.035 & 0.027 & 0.028 & $1 \cdot$ \\
\hline 0.038 & 0.041 & 0.038 & 0.040 & 11 \\
\hline 0.032 & 0.036 & 0.033 & 0.033 & ir \\
\hline 0.059 & 0.060 & 0.058 & 0.060 & سו \\
\hline 0.028 & 0.039 & 0.028 & 0.028 & If \\
\hline 0.034 & 0.050 & 0.034 & 0.034 & 10 \\
\hline 0.036 & 0.041 & 0.036 & 0.037 & 19 \\
\hline 0.029 & 0.034 & 0.030 & 0.030 & IV \\
\hline 0.040 & 0.039 & 0.039 & 0.043 & 11 \\
\hline 0.046 & 0.046 & 0.045 & 0.047 & 19 \\
\hline 0.050 & 0.052 & 0.050 & 0.051 & $r$. \\
\hline 0.038 & 0.043 & 0.038 & 0.039 & ميانكين \\
\hline
\end{tabular}

در معيار صحت هم فقط در جهار مورد، روش خايه، بهتر

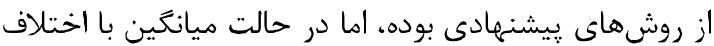
| • • •. روش يايه بجتر بوده است. در مورد ضريب تخطى،

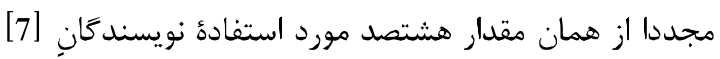
استفاده شده است.

مشابه با كاربرد قبل، مقدار بهينه را نيز مىتوان جستجو كرد؛ اما با همين مقدار نيز، برترى نسخههايى از شيوه

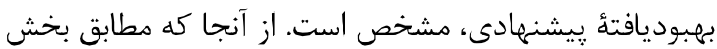
قبل، نقشهُ سهُانه مبتنى بر روشهاى شناسايى رگ موجود ايجاد مىشود، اين شيوه امكان آشكارسازى عروق بيدانشده با شيوءٔ مورد استفاده استخراج رگ را ندارد و تنهيا امكان دقيقتركردن برجسب گذارى در ناحيه مرزى نقشهسه دارد.

در اين بخش بهترين جواب روشهاى بيشنهادى از طريق مقايسه نتايج آستانههاى مختلف ماتريس آلفا و جواب واقعى مشخص شده است؛ اما درعمل اين شيوه مناسب نيست معائ 
segmentation in retinal images," in Medical Image Computing and Computer-Assisted Intervention MIC-CAI 2014, vol. 8673 of Lecture Notes in Computer Science, pp.634-641, Springer, 2014.

[19] V. M. Saffarzadeh, A. Osareh, and B. Shadgar, "Vessel segmentation in retinal images using multi-scale line operator and k-means clustering," Journal of Medical Signals \& Sensors, vol. 4, no.2, pp.122-129, 2014.

[20] G. Azzopardi, N. Strisciuglio, M. Vento, and N. Petkov, "Trainable COSFIRE filters for vessel delineation with application to retinal images," Medical Image Analysis, vol.19, no.1, pp.46-57, 2015.

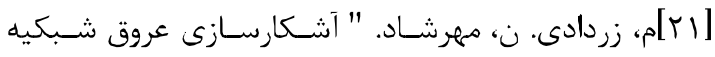

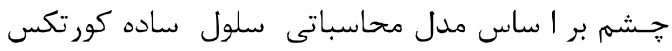

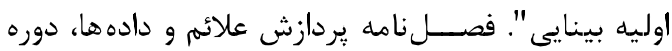

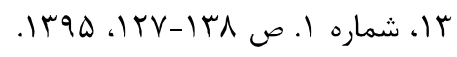

[21] M. Zardadi , and N. Mehrshad, "A New Approach to Retinal Vessel Segmentation by Using Computational Model of Simple Cells in Primary Visual Cortex". JSDP, vol. 13, no. 1, pp. 127-138, 2016.

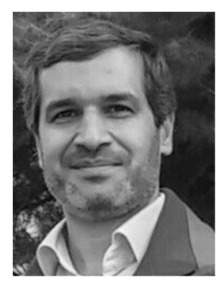

$$
\begin{aligned}
& \text { محمود امينطوسى، دورههاى } \\
& \text { كارشناسى و كارشناسى ارشد خود را در } \\
& \text { رشتههاى رياضى و مهندسى كامييوتر } \\
& \text { (نرم|فزار) در دانشغاه فردوسى به اتمام } \\
& \text { رسانده و دوره دكتراى خود را در رشته }
\end{aligned}
$$

مهندسى كامييوتر (هوش مصنوعى) در دانشخاه علم و صنعت رون

ايران كذرانده است. علايق يروهشى وى بينايى ماشين، يادكيرى ماشين و بهينهسازى تركيبياتى است.

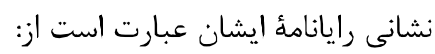

m.amintoosi@hsu.ac.ir
[5] P. G. Lee and Y. Wu, "L1 matting," IEEE in ICIP, pp.4665-4668, , 2010.

[6] I. Choi, S. Kim, M. S. Brown, and Y. W. Tai" ,A learning-based approach to reduce jpeg ar-tifacts in image matting," in 2013 IEEE International Conference on Computer Vision, pp.2880-2887, Dec 2013.

[7] Y. Zheng and C. Kambhametlu, "Learning based digital matting.," in 12th International Conference on Computer Vision, (Kyoto), pp.889-896, 2009.

[8] A. Levin, D. Lischinski, and Y. Weiss, "A closedform solution to natural image matting," IEEE Trans. Pattern Anal. Mach. Intell,. vol.30, no.2, pp.228-242, 2008.

[9] J. Sun, J. Jia, C.-K. Tang, and H.-Y. Shum, "Poisson matting," ACM Trans. Graph., vol.23, pp.315-321, Aug. 2004.

[10] Z. Zhang, Q. Zhu, and Y. Xie, "Learning based alpha matting using support vector regression, " in 2012 ,19th IEEE International Conference on Image Processing, pp. 2109-2112, Sept 2012.

[11] X. Li and Q. Cui, Parallel Accelerated Matting Method Based on Local Learning, pp.152-162 Cham: Springer International Publishing, 2017.

[12] K. Jung, K.Kim, andA. Jain, "Text information extraction in images and video: a survey," Pattern Recognition, vol.37, pp.977-997, 52004.

[13] N. Otsu, "A Threshold Selection Method from Gray-level Histograms," IEEE Transactions on Systems, Man and Cybernetics, vol.9, no.1, pp.6266, 1979.

[14] M. Fraz, P. Remagnino, A. Hoppe, B. Uyyanonvara, A. Rudnicka, C. Owen, and S. Barman, "Blood vessel segmentation methodologies in retinal images - a survey", Comput Methods Prog. Biomed., vol. 108, pp.407-433, Oct. 2012.

[15] M. T. Dehkordi, S. Sadri, and A. Doosthoseini, "A review of coronary vessel segmentation algorithms.," Journal of Medical Signals \& Sensors, vol.1, no.1, pp.49-54, 2011.

[16] P. Talwar, M. D. Gupta, "Alpha-matting based retinal vessel extraction," United States Patent Application 20160163041, June 2016.

[17] P. Bankhead, C. N. Scholfield, J. G. McGeown, and T. M. Curtis, "Fast retinal vessel detection and measurement using wavelets and edge location refinement.," PloS one, vol.7, no.3, 2012.

[18] J. I. Orlando , M. Blaschko, "Learning fullyconnected CRFs for blood vessel 
